\title{
Vorticella: A Protozoan for Bio-Inspired Engineering
}

\author{
Sangjin Ryu ${ }^{1, *}$, Rachel E. Pepper ${ }^{2}$, Moeto Nagai ${ }^{3}$ and Danielle C. France ${ }^{4}$ \\ 1 Department of Mechanical and Materials Engineering, University of Nebraska-Lincoln, Lincoln, \\ NE 68588, USA \\ 2 Department of Physics, University of Puget Sound, Tacoma, WA 98416, USA; rpepper@pugetsound.edu \\ 3 Department of Mechanical Engineering, Toyohashi University of Technology, Toyohashi 441-8580, Japan; \\ nagai@me.tut.ac.jp \\ 4 National Institute of Standards and Technology, Boulder, CO 80305, USA; danielle.france@nist.gov \\ * Correspondence: sangjin.ryu@unl.edu; Tel.: +1-402-472-4313
}

Academic Editors: Hyoung Jin Cho and Sung Kwon Cho

Received: 28 October 2016; Accepted: 20 December 2016; Published: 26 December 2016

\begin{abstract}
In this review, we introduce Vorticella as a model biological micromachine for microscale engineering systems. Vorticella has two motile organelles: the oral cilia of the zooid and the contractile spasmoneme in the stalk. The oral cilia beat periodically, generating a water flow that translates food particles toward the animal at speeds in the order of $0.1-1 \mathrm{~mm} / \mathrm{s}$. The ciliary flow of Vorticella has been characterized by experimental measurement and theoretical modeling, and tested for flow control and mixing in microfluidic systems. The spasmoneme contracts in a few milliseconds, coiling the stalk and moving the zooid at $15-90 \mathrm{~mm} / \mathrm{s}$. Because the spasmoneme generates tension in the order of $10-100 \mathrm{nN}$, powered by calcium ion binding, it serves as a model system for biomimetic actuators in microscale engineering systems. The spasmonemal contraction of Vorticella has been characterized by experimental measurement of its dynamics and energetics, and both live and extracted Vorticellae have been tested for moving microscale objects. We describe past work to elucidate the contraction mechanism of the spasmoneme, recognizing that past and continuing efforts will increase the possibilities of using the spasmoneme as a microscale actuator as well as leading towards bioinspired actuators mimicking the spasmoneme.
\end{abstract}

Keywords: Vorticella; oral cilia; feeding current; contractile stalk; spasmoneme; $\mathrm{Ca}^{2+}$-powered contraction; bioinspired engineering

\section{Introduction}

\subsection{Overview of Vorticella}

Among various microorganisms, protozoa have been widely studied as model systems for biology, physics, engineering and biomimetics. They form a diverse group of unicellular eukaryotic organisms including ciliates, flagellates and amoeboids. Among such protists, Vorticella has drawn the attention of scientists since Anthony van Leeuwenhoek first described its unique motility in his letter dated 9 October 1676 [1,2]. In a recent study, Vorticella was discovered in a fossil that is more than 200 million year old, bolstering the fossil record of soft-bodied organisms [3]. While we primarily describe biomechanical and biomimetic aspects of Vorticella, uncovered since the 1950s, it is worth noting that Vorticella has played a long and ongoing role in many fields of biological, physical and engineering study.

Vorticella is a suspension-feeding ciliate that lives in two forms: free swimming telotroch and sessile stalked trophont [4]. A sessile Vorticella consists of the zooid (inverted-bell-shaped cell body; usually about $30-40 \mu \mathrm{m}$ in diameter when contracted) and the stalk (3-4 $\mu \mathrm{m}$ in diameter and about $100 \mu \mathrm{m}$ in length) (Figure 1A). The zooid has two bands of cilia around the peristome, the mouth-like 
part of the zooid, which are used for suspension feeding. The cilia of the inner band generate water flow to draw food particles toward the zooid (Figure 1B), and these particles are filtered by the cilia of the outer band. An example of such a feeding current observed in the laboratory shows a vortex (Figure 1B), and it was observed that this flow could move micro-diameter particles at least $450 \mu \mathrm{m}$ away from the peristome with the maximum flow velocity of $360 \mu \mathrm{m} / \mathrm{s}[5,6]$.

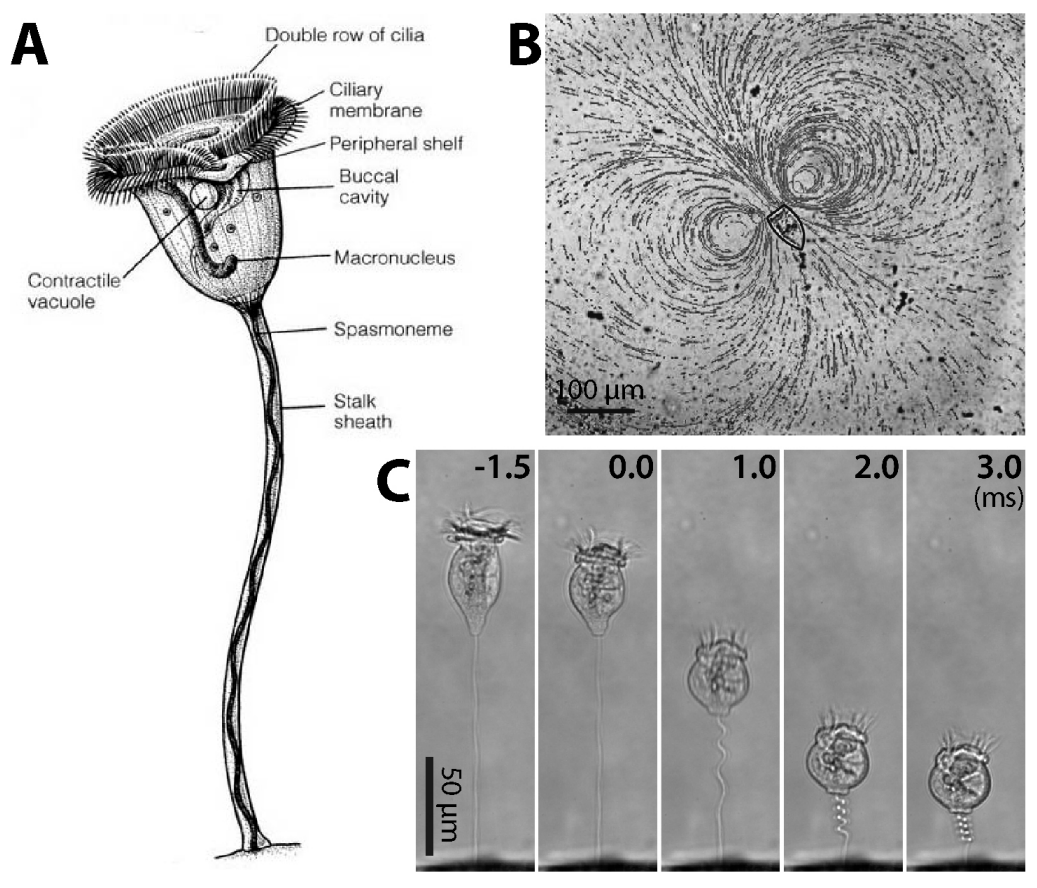

Figure 1. Sessile ciliate protozoan Vorticella. (A) Structure of Vorticella convallaria (reproduced from [7]); (B) pathlines of water flow generated by cilia beating of $V$. convallaria (reproduced from [8]); (C) sequential images of stalk contraction of $V$. convallaria (reproduced from [9]). The stalk begins to coil at $0 \mathrm{~ms}$.

In the sessile form, the vertex or scopula of the zooid is connected to the proximal end of the stalk while the distal end is rooted on a habitat surface (Figure 1A). Therefore, the stalk tethers the zooid to the habitat. The stalk also coils very quickly and moves the zooid toward the surface through the action of its contractile organelle, the spasmoneme (Figure 1C). Afterwards, the stalk slowly relaxes and moves the zooid away from the surface over a few seconds [10-12]. Although the stalk contraction-relaxation cycle of Vorticella has been hypothesized as a way either to avoid dangers, or to mix the surrounding fluid, no explanation is completely satisfactory.

During stalk contraction, Vorticella stops ciliary beating and contracts the zooid to a nearly spherical shape, and the stalk shortens to $20 \%-40 \%$ of its extended length in less than $10 \mathrm{~ms}$ (Figure $1 \mathrm{C}$ ). Therefore, Vorticella contracts at the average rate of $10-20 \mathrm{~mm} / \mathrm{s}$, and its zooid reaches a maximum speed of 60-90 mm/s [9,12-14]. In terms of specific velocity (body length/s), this maximum speed corresponds to 1200 body length/s, making Vorticella among the fastest living creatures using this metric [12]. It has also been estimated that in terms of specific power (power dissipation per mass) the stalk of Vorticella performs better than both automotive engines and striated muscle [15]. Recent measurements showed that live spasmonemes could generate a peak contractile force of $\sim 30 \mathrm{nN}$ with maximum power of $\sim 1.6 \mathrm{nW}$ during normal contraction, and isometric tension of $150-350 \mathrm{nN}[9,16]$.

In addition to its remarkable motility, the energy source for the stalk contraction makes Vorticella unique. While most biological contractile systems depend on ATP (adenosine triphosphate) for their biochemical fuel, the Vorticella spasmoneme is powered by calcium ions [17]. In the absence of ATP, extracted Vorticella stalks can repeat the contraction-relaxation cycle and generate contractile force, 
driven only by external calcium ions diffusing into the spasmoneme [17-23]. Because of its surpassing contractility and unique energy source, therefore, the Vorticella stalk is regarded as a candidate for $\mathrm{Ca}^{2+}$-powered cell motility and biomimetic actuating materials [24-29].

\subsection{Similar Microorganisms}

There are various other microorganisms which contract using $\mathrm{Ca}^{2+}$, such as Stentor and Paramecium. Among them, Zoothamnium and Carchesium are close to Vorticella in that these species also have contractile stalks (Figure 2). These larger ciliates have one main stalk with many branches ending in zooids, which is a major difference from Vorticella, which has only a single stalk and zooid. Upon stimulation, Zoothamnium contracts the entire colony into one large globule and then folds the main stalk (Figure 2A). In contrast, Carchesium contracts each zooid and its stalk separately (Figure 2B). This difference is due to a structural difference of the spasmoneme between the two species: the Zoothamnium spasmoneme is continuous among zooids in the colony, whereas the Carchesium spasmoneme is discontinuous between zooids. Because Zoothamnium and Carchesium have bigger spasmonemes than Vorticella does (the spasmoneme of Zoothamnium is about $30 \mu \mathrm{m}$ in diameter and $1 \mathrm{~mm}$ long [30]), they have also been employed for studying the spasmonemal contraction [10,30-57].
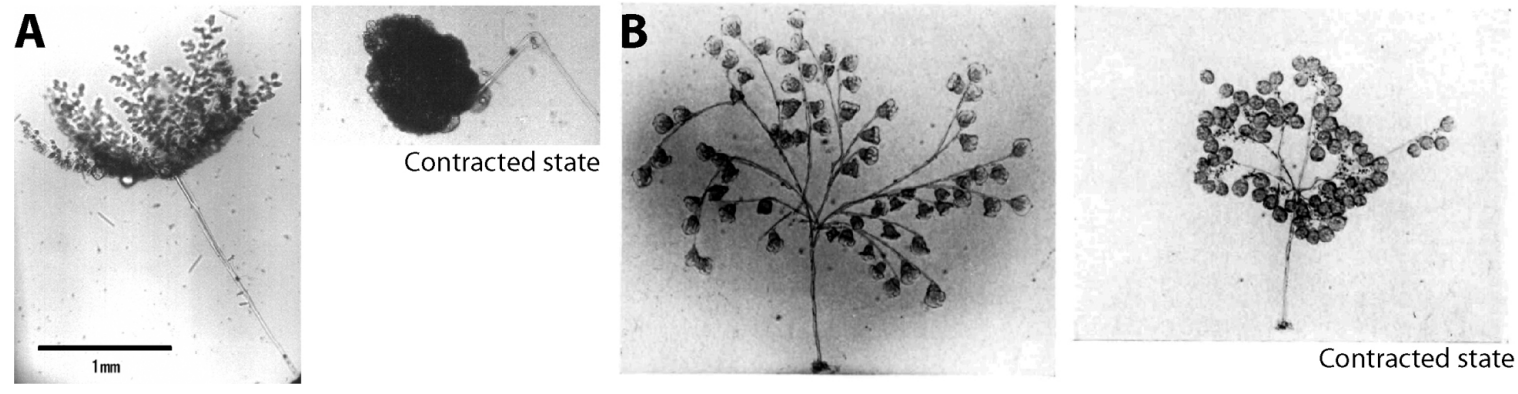

Figure 2. Other protozoa with $\mathrm{Ca}^{2+}$-driven stalk contraction. (A) Zoothamnium (reproduced from [58]); (B) Carchesium (reproduced from [59]).

\subsection{Focus of this Review}

In this review, we focus on Vorticella in the sessile form and summarize previous studies about its beating cilia and contractile stalk. Because the most recent reviews on Vorticella focus on its biological aspects and stalk contraction $[4,15,60]$, our review is complementary to them, providing an in-depth review of Vorticella from cellular mechanics and bio-inspired engineering perspectives. Furthermore, we intend to introduce Vorticella as a promising biological model system for bio-inspired engineering and biomimetics.

This review consists of two main parts. In the first part, we introduce the common features of cilia and review previous studies on the flow-generating-capability of the Vorticella cilia. Then, we discuss possibilities of using the Vorticella cilia for engineering applications. In the second section, we focus on the stalk of Vorticella and its $\mathrm{Ca}^{2+}$-powered contraction, including relevant studies on Zoothamnium and Carchesium. We also discuss how Vorticella with the contractile stalk can be used in microscale systems as an actuator and as a model for bio-inspired engineering.

\section{Cilia and Cilia-Generated Flow of Vorticella}

\subsection{Structure of Cilia Rows}

In his first description of Vorticella, Leeuwenhoek thought that Vorticella had two horns moving like horse ears near the oral part $[1,2]$. What he actually observed were beating oral cilia generating water flow. These cilia have a structure common to eukaryotic cells: each cilium includes a bundle of microtubules extending continuously for the length of the cilium with the so called " $9+2$ " pattern 
(Figure 3A,B) [61,62]. As the stiffest cellular filament, a microtubule is a hollow tube-like polymer of a globular protein tubulin. In this $9+2$ arrangement, a pair of singlet microtubules is surrounded by nine doublet microtubules.

Ciliary beating is characterized by a series of bends of the cilium, which depends on the sliding of adjacent doublet microtubules caused by dynein, one of the microtubule motor proteins [63]. Arms of dynein molecules are attached periodically along the length of the microtubule, and these arms of one doublet walk along the adjacent doublet powered by hydrolysis of ATP [62]. While each cilium beats periodically, their synchronized motion forms metachronal waves along the periphery of the oral part (Figure 3C,D), which causes a circulating current in the surrounding water (Figure 1B) [5]. This ciliary metachronal wave is a common motility mechanism among microorganisms [64-66].
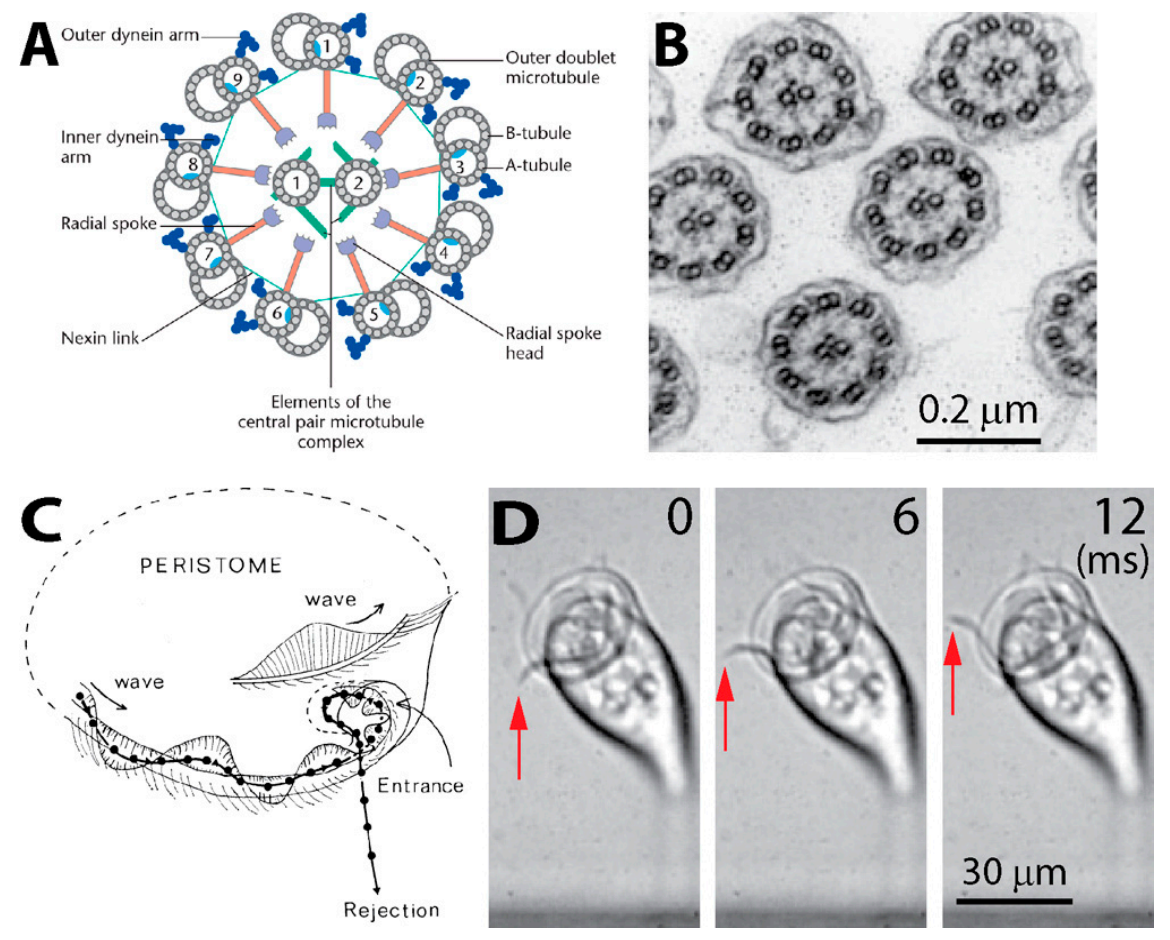

Figure 3. Oral cilia of Vorticella. (A) Cross-sectional view of the common structure of the cilium (reproduced from [63]). A cilium consists of nine circumferential doublet microtubules and one central pair of single microtubules $(9+2$ pattern). Dynein arms generate sliding motions between doublet microtubules, which bends the cilium; (B) cross-sectional view of the cilia of Vorticella. (reproduced from $[67,68]$ ); (C) a metachronal wave of cilia around the oral part of Vorticella (reproduced from [5]). The motion of the black particle shows transport of particles near the peristome; (D) red arrows show the metachronal ciliary wave of $V$. convallaria.

\subsection{Ciliary Performance}

Using Vorticella as a model protozoan for microscale fluid control requires evaluating its ciliary performance and understanding the flow caused by the cilia. Such studies experimentally measured the field and strength of the ciliary flow of Vorticella by tracing particles in the flow. Fluid dynamics modeling has also been employed to model the ciliary flow based on the fact that the flow is dominated by viscosity. Characterizations made with both experiments and theoretical models are discussed here.

\subsubsection{Flow Measurement}

Sleigh and Barlow first examined the feeding current of $V$. convallaria by tracing micron-sized particles in the vicinity of the zooid using high-speed cinematography [5]. They observed that $17 \mu \mathrm{m}$-long cilia beat at about $50 \mathrm{~Hz}$ with the tip speed of $4 \mathrm{~mm} / \mathrm{s}$ while particles moved at $2.5 \mathrm{~mm} / \mathrm{s}$ 
near ciliary tips. This ciliary beating enabled $V$. convallaria to draw particles $450 \mu \mathrm{m}$ away from the oral part and to collect particles in a volume of about $0.3 \mathrm{~mm}^{3}$.

Later, Vopel et al. measured the velocity of the feeding current of a marine Vorticella using a flow microsensor [69]. The measured flow velocity was about $18 \mathrm{~mm} / \mathrm{s}$ and $2.6 \mathrm{~mm} / \mathrm{s}$ at a horizontal distance of $50 \mu \mathrm{m}$ and $350 \mu \mathrm{m}$ from the oral part, respectively, and $0.8 \mathrm{~mm} / \mathrm{s}$ at the stalk base. Having observed that the Vorticella moved the surrounding seawater at least $400 \mu \mathrm{m}$ from the zooid, which agrees with Sleigh and Barlow's observation, Vopel et al. suggested that the ciliate could generate sufficient feeding flow by raising the zooid above the substrate by the stalk.

Recently, Nagai et al. rigorously measured the two-dimensional (2D) velocity components of the feeding current of $V$. picta using the confocal micro-particle image velocimetry ( $\mu$-PIV) [6]. Their reconstructed flow velocity field showed the same double-vortex structure (Figure 4A) seen by Sleigh and Barlow [5]. Although Sleigh and Barlow extrapolated an axisymmetric toroidal vortex structure from these twin vortices, truly three-dimensional flow measurement is still required to validate the seemingly toroidal feeding current of Vorticella.

Nagai et al. observed the maximum flow speed of about $360 \mu \mathrm{m} / \mathrm{s}$ occurring in front of the peristome, and evaluated the volume flow rate toward the oral part to be about $3 \times 10^{-4} \mathrm{~mm}^{3} / \mathrm{s}$. This maximum flow speed is about one order of magnitude lower than that of the previous two studies. This is because flow speed measurements depend on the region of the measurement in the vicinity of cilia and the resolution of imaging. It is noticeable that $1 / 3$ of this inflow was carried from fresh water whereas $2 / 3$ was recirculated. Therefore, $V$. picta appeared to clear water at a rate of $0.36 \mathrm{~mm}^{3} / \mathrm{h}$ and to collect particles from a fluid volume of $1.7 \times 10^{-3} \mathrm{~mm}^{3}$.
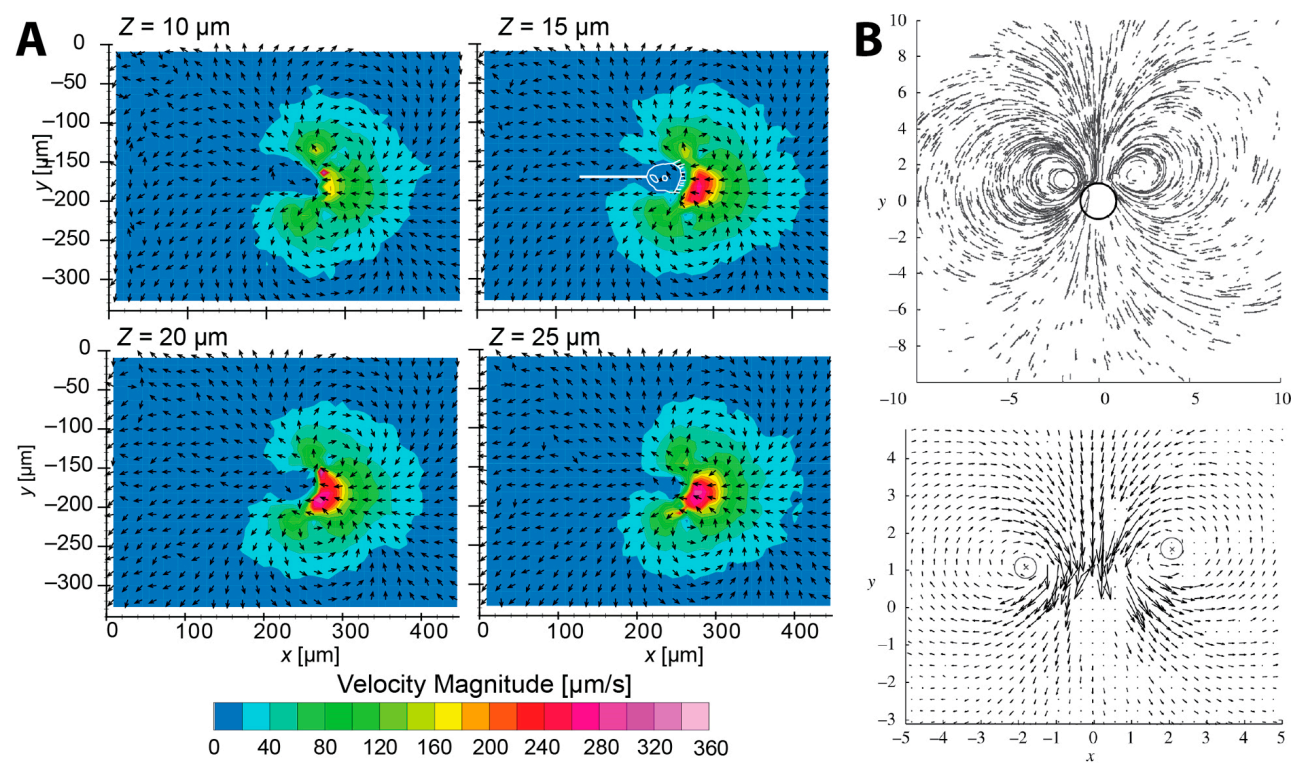

Figure 4. Feeding current of Vorticella. (A) $\mu$-PIV measurements of the feeding current of $V$. picta (reproduced from [6]). 2D flow fields of $x$ - and $y$-velocity components were measured at various $z$ planes; (B) particle paths and flow field obtained from the feeding current of $V$. convallaria shown in Figure 1B. The circle in the top figure represents the zooid, and the two circles in the bottom figure show the center of eddies (reproduced from [8]).

Pepper et al. also measured the feeding current of $V$. convallaria using particle tracking velocimetry (PTV) (Figures 1B and 4B) [8]. Individual V. covallaria cells were anchored to the thin edge of a coverslip, confined between two closely-spaced surfaces. Having observed that increasing the spacing between the confining surfaces increased the size of the observed vortices, Pepper et al. suggested that the feeding flow in nature without confining boundaries nearby might differ significantly from the 
dual-vortex structure seen for Vorticella sandwiched between surfaces. A full 3D measurement of the feeding current around a Vorticella without nearby boundaries has not yet been made.

\subsubsection{Fluid Dynamic Model}

Since Vorticellae are small and their feeding current is relatively slow, they feed in the regime of low Reynolds number flow (i.e., Stokes flow) [70]. The Reynolds number is the ratio of inertial to viscous forces in a fluid flow, and is defined as $R e=U L / v$. Here, $U$ and $L$ are a characteristic velocity and length of the flow, and $v$ is the kinematic viscosity of the fluid. For Vorticella in water (zooid diameter $L \approx 40 \mu \mathrm{m}$ and feeding flow speed $U \approx 100 \mu \mathrm{m} / \mathrm{s}$ ), a typical Reynolds number of the feeding current is $4 \times 10^{-3}$. Thus, viscous forces dominate over inertia forces in the feeding current of Vorticella.

The feeding current of microscopic suspension feeders including Vorticella is often modeled as a single stokeslet, a point force in Stokes flow [8,71-82]. A stokeslet in free space (Figure 5A) does not have the characteristic toroidal flow pattern seen in Figure 4, whereas several different models of Vorticella feeding between two closely-spaced parallel boundaries result in such recirculating flow with tight, circular streamlines (Figure 5B) $[8,74,75]$. This theoretical observation suggests that the circular vortices are due to the two boundaries sandwiching the organism, which are glass surfaces present in most experimental observations of Vorticella feeding flow [8,71,74]. Indeed, the feeding flow field produced by Vorticella is likely to be determined mostly by the geometry of nearby boundaries [74].

A more realistic model for feeding Vorticellae is likely a stokeslet forcing fluid towards a single plane which represents the habitat substrate. Having modeled Vorticella as such a stokeslet, Blake and Otto found that the feeding current consists of a toroidal vortex around the organism (Figure 5C), but not with the characteristic circular shape found in experiments and with a stokeslet between two boundaries [72].
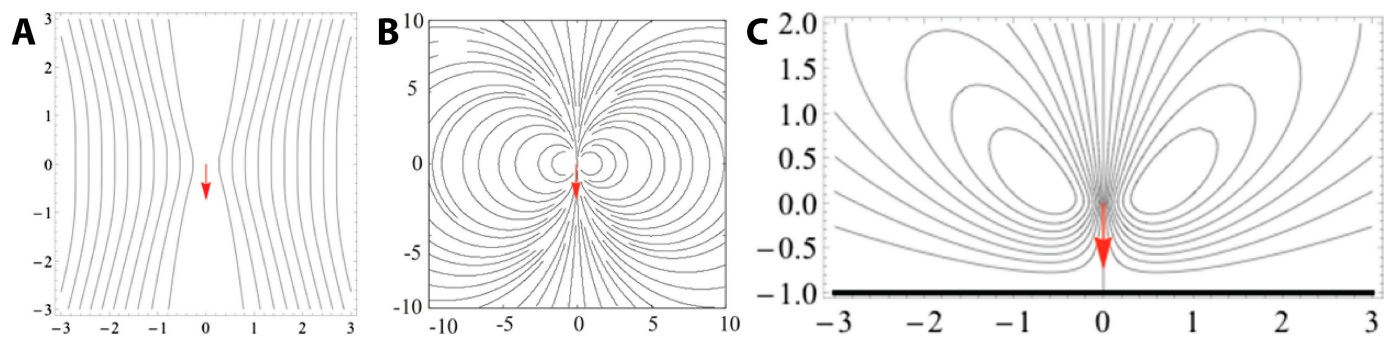

Figure 5. Streamlines around a stokeslet in various geometries. The red arrow represents the direction of the stokeslet force and thus the orientation of the Vorticella zooid axis (arrow points from the peristome to the scopula). (A) Stokeslet in free space; (B) stokeslet between two parallel planes (reproduced from [8]); (C) stokeslet pointing perpendicular to a single plane boundary, which is indicated by the bold black line.

Recently, Pepper et al. showed that the single stokeslet model with nearby boundaries agrees well with experimentally-measured feeding flow fields around Vorticella [8]. They also confirmed that the size of these eddies is determined by the distance between the two boundaries, which indicates that the eddies would not be present if no boundaries were nearby, as shown by Figure 5A. Moreover, they estimated that the total force exerted by the cilia of $V$. convallaria on the surrounding water is $0.05-0.5 \mathrm{nN}[80,83,84]$. It has also been shown that when only one boundary is nearby, the fluid flow changes dramatically depending on the angle of Vorticella to the surface [84]. Therefore, effects of nearby boundaries need to be considered when utilizing the ciliary flow of Vorticella and other microorganisms. 


\subsection{Engineering Applications}

It has been suggested that the biological motors of microorganisms can be used or mimicked in microsystems to reduce the overall size of devices, and cilia beating has been envisaged as a potential strategy for inducing fluid flow and mixing in microsystems [85]. Cilia-mimicking devices such as artificial cilia have succeeded in generating pumping and mixing [86-96], but they require external power sources for operation, which enlarges the system. In contrast, cellular cilia do not require such external sources because they convert in situ biochemical energy to mechanical work [97], which seems ideal for components of microsystems. For instance, live carpets of flagellated bacteria have been used to produce directional flows and thus to transport fluid [98-100].

Similarly, the cilia of live Vorticella can function as a driving source for fluid motion in microfluidic devices. Recently, Nagai et al. used the oral cilia motion of live $V$. convallaria in a microchannel for mixing enhancement (Figure 6) [101,102]. Several V. convallaria cells on a channel surface caused active mixing between two streams in a Y-channel based on fluid transport generated by their cilia. Another possible application could be fluid pumping, for which multiple Vorticellae generate directional flow and thus transport target objects in the flow direction. For better performance, Vorticellae can be patterned in microsystems using a guiding flow into the system [101,103]. However, drawbacks exist in using live Vorticellae in the microsystem, such as providing nutrients and removing waste for sustainable culture of the microorganisms, controlling their location, and packaging fluidic systems for controlling microenvironments.
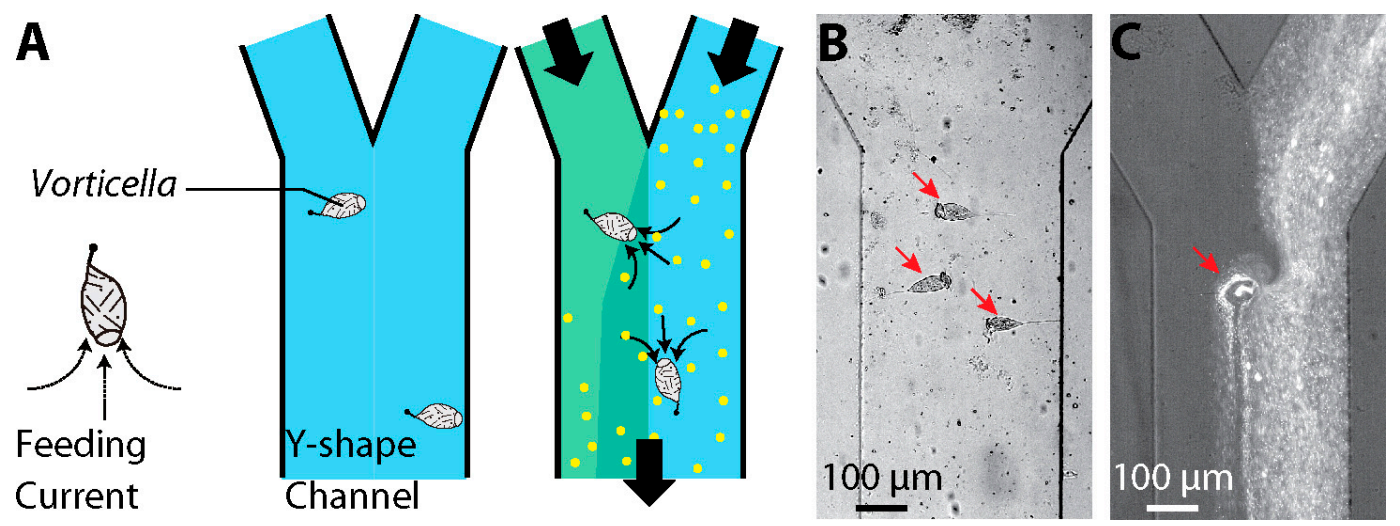

Figure 6. Vorticella as a microfluidic mixer (reproduced from [101]). (A) Schematic of using the Vorticella cilia for micromixing; (B) V. convallaria cells in a Y-channel; (C) transport of microparticles by a single $V$. convallaria cell, and resultant mixing between two streams in the Y-channel.

\section{Stalk and Ultrafast Contraction of Vorticella}

\subsection{Structure and Coiling of the Stalk}

Arguably, the vast majority of the attention paid to sessile Vorticella has focused on the contractility of its stalk and thus the stalk structure. Although the coiling stalk of Vorticella was witnessed centuries ago under the first microscope [1,2], it has taken more modern investigations at various length scales to reveal the structural elements that enact Vorticella's rapid movement.

The Vorticella stalk consists of a fibrous contractile organelle (the spasmoneme), a relatively robust sheath, a matrix of tiny fibers (the fibrillar matrix), and rod-like bundles of filaments (the bâtonnets) stiffening the sheath (Figure 7A). The spasmoneme runs through the entire length of the stalk as a left-handed helix [21], whereas the bâtonnets run as a right-handed helix, always located on the opposite side of the sheath from the spasmoneme. The spasmoneme is intracellular, connected with the zooid whereas the sheath material is extracellular and primarily considered structural in nature. 


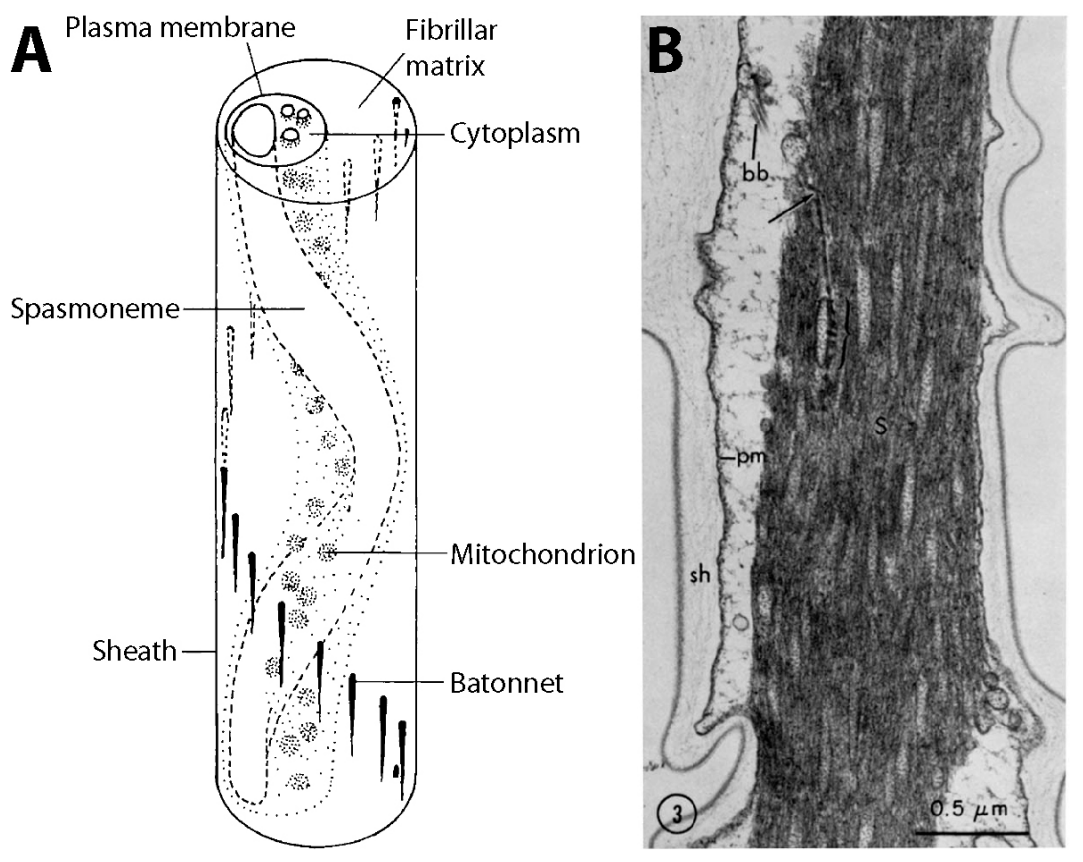

Figure 7. Structure of the Vorticella stalk. (A) Schematic of the stalk (reproduced from [37]); (B) cross-sectional micrograph of the stalk showing that the spasmoneme is composed of 3-4 nm-diameter fibrils (reproduced from [67]).

Coiling of the stalk involves the mechanical interplay of these elements. As the stalk coils, the spasmoneme takes a shorter path through the coil while the bâtonnets remain on the outside of the coil indicating the least deformable part of the sheath and stalk [34,37]. During the course of rapid contraction, the spasmoneme twists itself, and the stored strain is relaxed by the rotation of the zooid at the end of contraction [12]. Re-extension or relaxation of the stalk is also a mechanical interplay of these elements. The roles of each element have not been precisely defined, although the elastic restoring force of the deformed sheath was suggested to be responsible for the stalk re-extension [13].

The fibrous structure of the spasmoneme was first shown in transmission electron microscope (TEM) images in the early 1970s (Figure 7B) [37,104]. These early observations revealed hundreds of filaments, each roughly $2-4 \mathrm{~nm}$ in diameter, in the contracted spasmoneme. These fibrils are interspersed with tubules which are roughly $50 \mathrm{~nm}$ in diameter with $\sim 250 \mathrm{~nm}$ spacing. These round membranated structures have been proposed as mitochondria and/or calcium storage sites $[37,104]$.

As previously mentioned, calcium ions induce and power the spasmonemal contraction [17]. In the absence of ATP, the permeabilized stalk can coil if the free $\mathrm{Ca}^{2+}$ concentration of the medium $\left(\left[\mathrm{Ca}^{2+}\right]_{\text {free }}\right.$ ) is higher than $10^{-6} \mathrm{M}$ (Figure $8 \mathrm{~A}$ ) $[19,20,23]$. This is because external calcium ions can diffuse into the stalk and trigger the spasmoneme. The permeabilized stalk remains extended when $\left[\mathrm{Ca}^{2+}\right]_{\text {free }}<10^{-8} \mathrm{M}$. The stalk can repeat the contraction-relaxation cycle and generate tension upon changes in $\left[\mathrm{Ca}^{2+}\right]_{\text {free, }}$ although it loses contractility over repeated cycles (Figure 8B).

Should the membranous tubules seen by TEM be proven to contain high concentrations of calcium, they could feasibly serve as energy reservoirs for the spasmoneme [4,37]. As a contraction is triggered, calcium is thought to be released from the tubules [37,105]. Relaxation of the stalk then requires that calcium be pumped back to its storage organelles by ATP-dependent pumps $[48,56]$. These two processes occur on vastly different time scales: milliseconds for contraction and seconds for relaxation. 

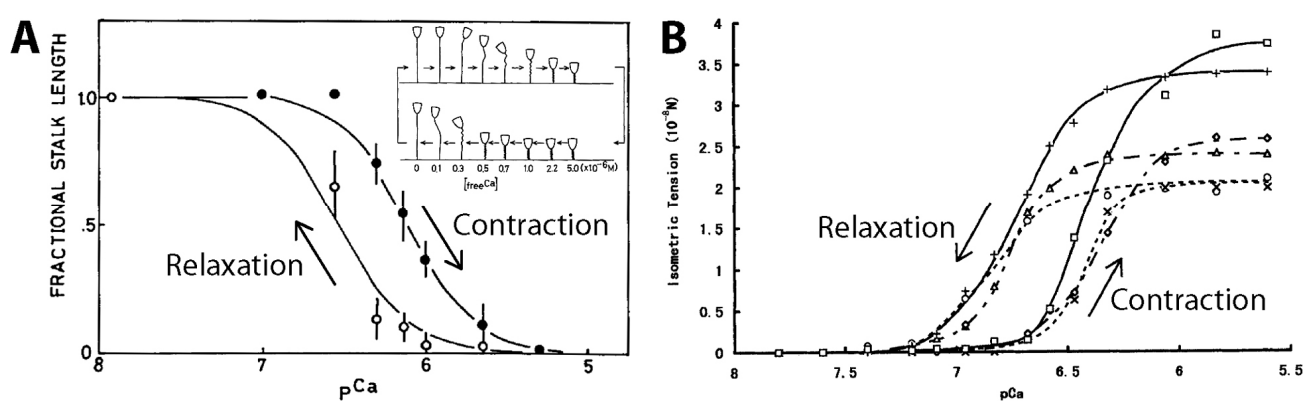

Figure 8. Calcium-dependency of Vorticella's stalk contraction. (A) The contraction-relaxation cycle of the extracted stalks of $V$. convallaria responding to changes in $\left[\mathrm{Ca}^{2+}\right]_{\text {free }}$ (reproduced from [20]). Inset: Shape changes of $V$. convallaria depending on $\left[\mathrm{Ca}^{2+}\right]_{\text {free }}$ (reproduced from [58]); (B) isometric tension developed by the extracted stalk of $V$. convallaria responding to changes in $\left[\mathrm{Ca}^{2+}\right]_{\text {free }}$ (reproduced from [23]). Here, pCa $=-\log _{10}\left[\mathrm{Ca}^{2+}\right]_{\text {free }}$.

\subsection{Contraction Mechanism}

When considered together, the stalk elements point towards Vorticella stalk coiling being carried out by a fibrous, ordered substructure of the spasmoneme actuated by calcium ions. Two prominent models were proposed that relied heavily on the filamentous structure of the spasmoneme. In the electrostatic model (Figure 9A) [17], the nanofibrils of the spasmoneme are negatively charged, so they are aligned in parallel due to electrostatic repulsive force among the filaments. Binding of calcium ions neutralizes the charged filaments, which results in the collapse of the filaments and thus contraction of the spasmoneme. However, the electrostatic model does not consider the $\mathrm{Ca}^{2+}$-specificity of the spasmoneme $[46,48]$. The spasmonemal contraction can be induced by a divalent cation of around the same size as $\mathrm{Ca}^{2+}$ whereas electrostatic screening by monovalent salt ions cannot do so [106]. The second model assumes the spasmoneme to be a rubber-like material $[38,44,56]$, wherein calcium binding induces the intramolecular folding of contractile elements or peptides. A common drawback of the above models is that they do not consider the biochemistry of the spasmoneme components.
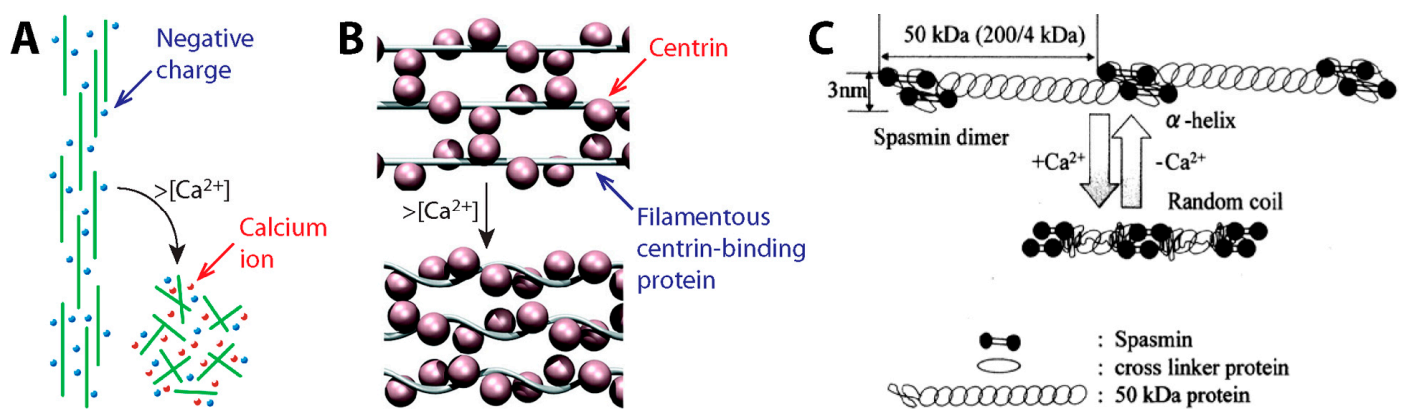

Figure 9. Suggested models for the Vorticella spasmoneme. (A) Electrostatic model based on the concept of the entropic spring (reproduced from [15]); (B) two-component model suggested for the centrin-based infraciliary lattice of Paramecium (reproduced from [107]); (C) two-component model considering the protein components (spasmin and spaconnectin) of the spasmoneme (reproduced from [58]).

Routledge et al. first identified the major protein component of the Vorticella spasmoneme, a 20 kilodalton $(\mathrm{kDa}) \mathrm{Ca}^{2+}$-binding protein termed spasmin [40]. Spasmin is negatively charged and becomes more hydrophobic upon calcium binding $[40,48,49,108]$. Because of its abundance in the spasmoneme and affinity for calcium, spasmin is widely considered to be the actuating protein of the spasmoneme. Spasmin appears to have a binding partner in the spasmoneme, a $50 \mathrm{kDa}$ 
spasmin-receptor protein named spaconnectin $[55,56,109,110]$. This protein pair is also found in the spasmoneme of Carchesium and Zoothamnium [110]. However, the roles of spasmin and spaconnectin in Vorticella contractility have yet to be identified.

Centrin, a homolog of spasmin, provides clues to elucidate the contraction mechanism of the spasmoneme. As a eukaryotic signature protein, centrin is a highly conserved $\mathrm{Ca}^{2+}$-binding protein found contractile organelles of some eukaryotic cells [55,111-114]. Because centrin does not readily form nanofibers on its own, its binding partners have been identified which have multiple repeated conserved sites for centrin binding and higher fibril-forming potential [115-118]. For instance, the contractile infraciliary lattice (ICL) of Paramecium contains centrin and a centrin-binding protein named PtCenBP1 (Figure 9B) [107]. It has been suggested that the $\mathrm{Ca}^{2+}$-responding nanofilaments of the ICL consist of PtCenBP1 molecules containing repeated centrin-binding motifs, so multiple centrin molecules bind to each extended PtCenBP1 molecule at low $\left[\mathrm{Ca}^{2+}\right]_{\text {free }}$. Upon influx of $\mathrm{Ca}^{2+}$, centrin molecules undergo conformational changes, which causes shortening of the filaments and thus the contraction of the ICL [107].

Recently, a similar two-component model has been proposed for the spasmoneme based on spasmin and spaconnectin (Figure 9C) [58]. This model assumes that the spasmonemal nanofibrils consist of an $\alpha$-helix of spaconnectin joining a pair of spasmin molecules. Upon increase in $\left[\mathrm{Ca}^{2+}\right]_{\text {free }}$, spaconnectin molecules become random coils, so the filaments shorten. This two-component model leaves room to accommodate several key aspects from the experimental evidence: specificity for calcium and hydrophobic interactions that become available when spasmin binds calcium. Identifying the contraction mechanism of the spasmoneme based on the roles of its protein components is crucial for exploiting the $\mathrm{Ca}^{2+}$-induced contraction of the spasmoneme in bio-inspired engineering.

\subsection{Contractile Performance}

Studies on the stalk contractility of Vorticella not only give us insights into how the spasmoneme operates, but also frame the motor capabilities of the spasmoneme as a model for bioinspired actuators [26]. Such studies measured key parameters including contraction speed, coiling propagation speed, contractile force (or tension), mechanical work, and power, using both live and extracted Vorticella cells. High-speed imaging techniques have enabled observations of the millisecond contraction sequence of live Vorticella. In contrast, extracted cells have enabled easier manipulations and observations of the spasmonemal contraction as shown in Figure 8, and if stored frozen in glycerin, remain contractile for up to several months [19]. Observations made with both live and extracted cells are discussed here.

\subsubsection{Dynamics of Stalk Contraction}

Two types of speed measurements have been taken for Vorticella: the contracting speed of the whole stalk, which equals the moving speed of the zooid during stalk contraction, and the propagation speed of the contraction onset, which proceeds from the zooid to the distal end of the stalk (Figure 1C). The former is defined by the capabilities of the contractile machinery as a whole, while the latter is believed to be dictated by the molecular signaling mechanism that drives calcium release within the spasmoneme, thereby instigating contraction.

Various imaging methods have been employed for time-resolved investigations of live Vorticella's contraction. To the best knowledge of the authors, Ueda made the first measurements of the contraction speed of Carchesium polypinum, which was $17.8-24.7 \mathrm{~cm} / \mathrm{s}$, using a photographic method for which a detailed description was not given [32]. Later, Sugi projected the image of the contracting stalk of $C$. polypinum, with carbon granules attached, through a narrow slit onto a rotating photographic paper roll, and measured that the contraction propagation speed was $20-50 \mathrm{~cm} / \mathrm{s}$, which is higher than the contraction speed [33]. A similar approach was employed for Vorticella by Katoh and Naitoh, and the measured contraction speed $(6.7 \mathrm{~cm} / \mathrm{s})$ was lower than that of $C$. polypinum [11]. These measurements are summarized in Table 1 along with the latent period (the time between observed cell body contraction and the onset of stalk contraction). 
Early observations with high-speed cameras were instigated by Jones et al. with $V$. difficilis, $V$. campanula, and Carchesium [119]. Later, the dynamics of V. convallaria's stalk contraction was extensively investigated by Moriyama et al. [12], Upadhyaya et al. [14], Ryu and Matsudaira [9] and Kamiguri et al. [120]. In these video microscopy studies, a Vorticella lying in the focal plane of the microscope was imaged (Figure 1C), and the time course of contraction speed was obtained from the stalk length change directly measured from sequential images captured during contraction (Figure 10A). Also, the propagation speed of stalk coiling could be measured by measuring a time difference in coiling initiation between two points on the stalk. As summarized in Table 1, Vorticella in water reaches the maximum contraction speed of $1.5-9 \mathrm{~cm} / \mathrm{s}$ at $1-2 \mathrm{~ms}$ after the initiation of the stalk contraction, and its stalk coiling propagates at a speed of about $10 \mathrm{~cm} / \mathrm{s}$ and is completed in 4-9 ms.
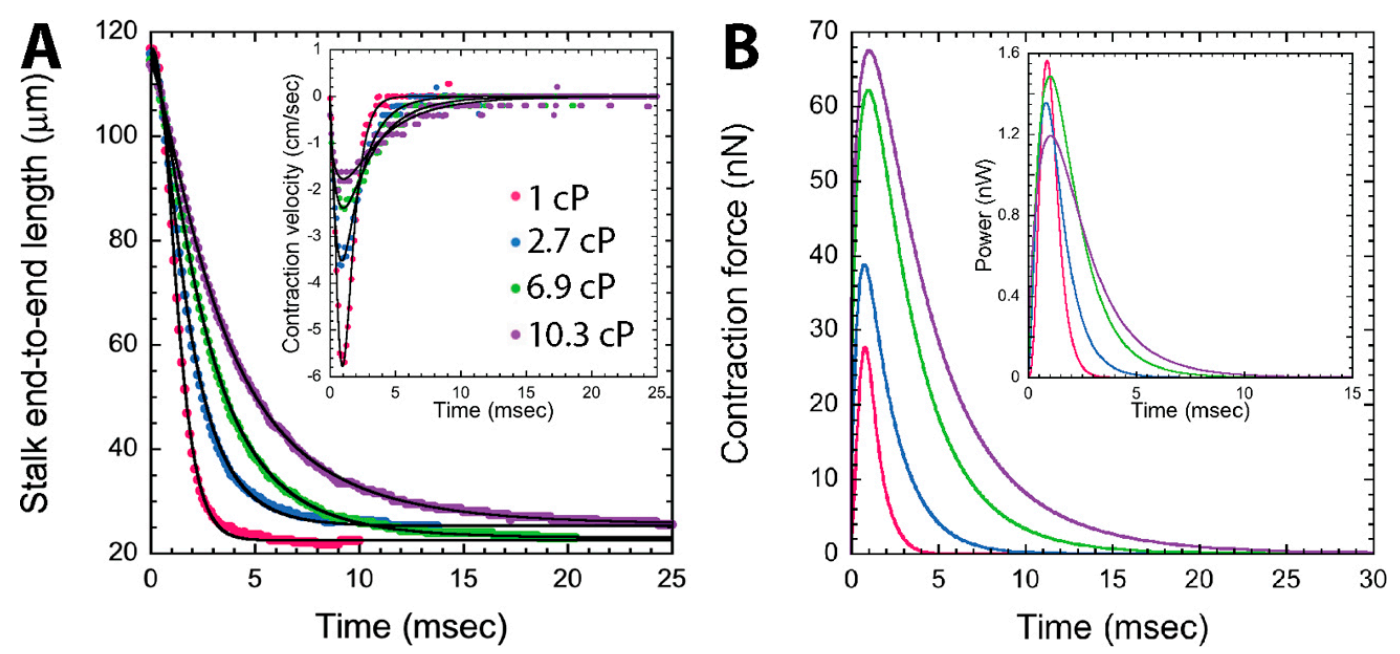

Figure 10. The stalk contraction dynamics and energetics of $V$. convallaria (reproduced from [9]). (A) Time courses of the stalk length and contraction speed (inset); (B) contractile force and power (inset) calculated from the velocity profile. $1 \mathrm{cP}$ (centipoise) is the dynamic viscosity of water $(=0.1 \mathrm{~Pa} \cdot \mathrm{s})$. As the medium viscosity increased, V. convallaria contracted slower with higher contractile force while the peak power was limited.

\subsubsection{Model-Based Tension Measurements}

Given a measure of contraction speed, the contractile force of the spasmoneme can be estimated using fluid dynamics modeling. In the model, the contracted zooid is assumed to be a solid spherical body moving in a viscous liquid. During translational motion caused by the coiling stalk, the zooid experiences the tension from the stalk and the drag force from the surrounding liquid. Although the net force of the two components accelerates the zooid, the contractile force can be equated to the drag because the resultant inertial force of the zooid is negligible due to the small mass of the zooid. Therefore, the spasmonemal tension can be determined from fluid dynamics calculations.

Amos first utilized this modeling approach for Vorticella using Stokes' law [13]. This drag formula calculates drag force on a sphere moving at low Reynolds numbers $(\operatorname{Re}=2 R U / \nu<<1)$ to be $6 \pi \mu R U$, where $\mu$ is the liquid viscosity, $R$ and $U$ are the radius and speed of the zooid, respectively. Using Jones et al.'s study [119], he estimated that the mean contraction force and minimum work of the Vorticella spasmoneme were $8.7 \mathrm{nN}$ and $0.69 \mathrm{pJ}$, respectively [13,44]. Moriyama et al. [12] and Upadhyaya et al. [14] employed the same approach and high-speed imaging, and they estimated the peak contraction force of $V$. convallaria to be $55.8 \mathrm{nN}$ and $\sim 30 \mathrm{nN}$, respectively (Table 2).

Later, computational fluid dynamics (CFD) simulations were utilized by Ryu and Matsudaira for more rigorous estimations. They modeled a contracting $V$. convallaria as a sphere moving toward a solid plane, simulated water flow caused by the sphere translating with the measured profile of the stalk length change, and then calculated the drag on the zooid from the simulated water flow. 
Their simulation showed that $V$. convallaria contracted in water with the maximum tension of $28 \mathrm{nN}$ and maximum power of $1.6 \mathrm{nW}$, and that its spasmoneme converted chemical energy from $\mathrm{Ca}^{2+}$-binding to mechanical work of $1.64 \mathrm{pJ}$ with energy conversion efficiency of $8 \%$ (Figure 10B). Here, the efficiency is a ratio of mechanical work done by the spasmoneme to chemical energy available from calcium binding.

\subsubsection{Experimental Tension Measurements}

Hydrodynamic force estimations suggest the lower limit of the contractile force of the Vorticella spasmoneme because more force must have been generated to deform the sheath and to overcome the internal resistance of the stalk [48]. In contrast, the upper limit on contractile force is the isometric tension of the spasmoneme that is generated when the stalk is not allowed to shorten. Therefore, measuring the upper limit involves applying external resistances to Vorticella to hinder full contraction.

Both the high contraction speed and small size of Vorticella make the manipulations needed for isometric tension measurements challenging. Size difficulties were circumvented by using Carchesium and Zoothamnium, and the tensile stress of their spasmonemes was measured to be $6-78 \mathrm{kPa}$ $\left(1 \mathrm{~Pa}=1 \mathrm{~N} / \mathrm{m}^{2}\right)[31,38,39,42]$. Speed difficulties were overcome by using extracted stalks. Moriyama et al. induced tension of the extracted stalk of $V$. convallaria by increasing $\left[\mathrm{Ca}^{2+}\right]_{\text {free }}$ while fixing both ends of the stalk, which measured isometric tension (Figure 8B) [23]. The measured isometric tension was $40 \mathrm{nN}$ on average and $120 \mathrm{nN}$ at maximum, which corresponds to tensile stresses of 35-51 kPa.

One method attempted to directly measure the isometric tension of live Vorticella was to retard stalk contraction by increasing the medium viscosity $[9,14]$. Under increased viscous drag, V. convallaria took a longer time to complete stalk contraction with lower speed, and generated higher contractile force to overcome increased resistance (Figure 10). Upadhyaya et al. first noticed that power dissipation of multiple $V$. convallaria cells, which is the product of force and velocity, was 1-3 nW even with significant increase in the medium viscosity [14]. Recently, Kamiguri et al. used various polymer additives and made similar observations [121]. The idea of power-limited contraction was more rigorously examined by Ryu and Matsudaira [9], who calculated that the power dissipation of a single $V$. convallaria was maintained at $1.2-1.6 \mathrm{nW}$ over one order of magnitude change in the viscosity (Figure 10B inset). They also evaluated that the energy conversion efficiency of the spasmoneme was limited to $18 \%$. However, it is likely impossible to estimate the isometric tension of the spasmoneme by increasing the medium viscosity because Vorticella can contract to its full extent even in highly viscous media.

True measurements of the isometric tension are possible only when a stall or resistance force is directly exerted on contracting Vorticella. Recently, Ryu et al. employed a microfluidic channel to hydrodynamically stall the stalk contraction of $V$. convallaria [16]. Drag forces applied by controlled fluid flow opposing contraction were high enough to overcome the Vorticella contractility and stop it short of completion (Figure 11A). The estimated isometric tension ranged from 150 to $330 \mathrm{nN}$, and it appeared to increase in proportion to the stalk length (Figure 11B). This linear dependence of the isometric tension on the stalk length suggests that the $1 \mu \mathrm{m}$ of the spasmoneme could generate a tension of up to $\sim 2.5 \mathrm{nN}$.

Stall force has also been measured by suctioning the Vorticella cell body to a micropipette and calculating the spasmonemal force from pipette stiffness and deflection or pressure difference applied by the pipette. Both France [122] and Apolinar-Iribe et al. [123] employed a micropipette and measured the contractile force of live Vorticella to be in the hundreds of nanonewtons. 

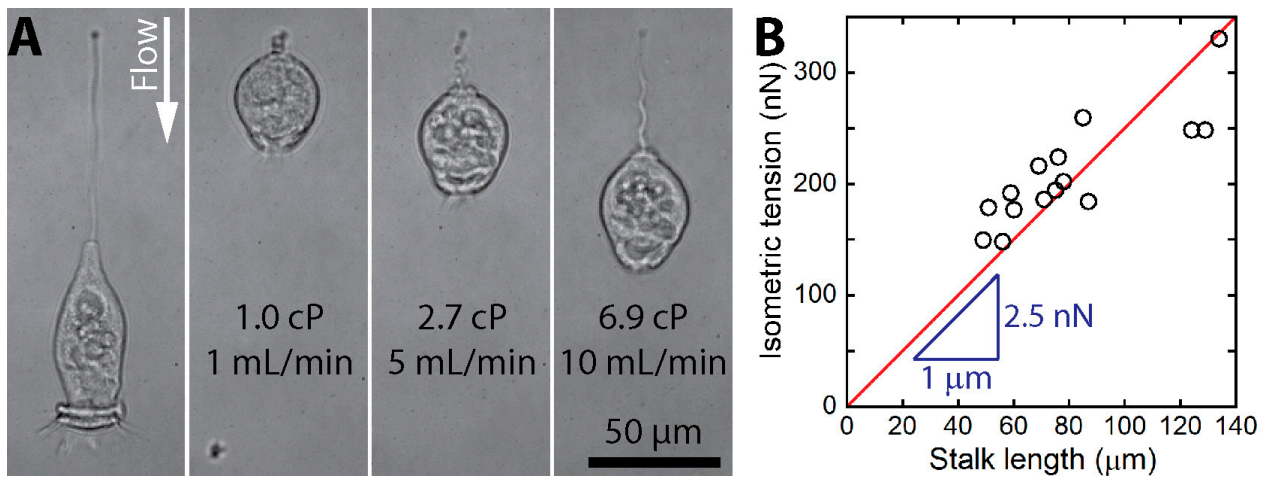

Figure 11. Isometric force measurements of live V. convallaria (reproduced from [16]). (A) V. convallaria stalled by viscous drag in a microchannel. The leftmost picture shows extended state, and the subsequent show contracted states under different flow conditions; (B) measured isometric tensions increased from 150 to $330 \mathrm{nN}$ with a linear dependence on the stalk length, which suggests that the $1 \mu \mathrm{m}$ of the spasmoneme can generate a tension of up to $\sim 2.5 \mathrm{nN}$.

\subsection{Comparison with Other Motors}

It is worthwhile to compare the contractility of the Vorticella spasmoneme with other contractile systems. In addition to protozoa with $\mathrm{Ca}^{2+}$-powered contractile organelles, leguminous plants have 2-4 $\mu \mathrm{m}$ diameter $\mathrm{Ca}^{2+}$-dependent contractile protein bodies in their sieve tubes, forisomes [26,124-127]. Forisomes repeat contraction-relaxation cycles responding to changes in $\mathrm{Ca}^{2+}$ concentration in ATP-depleted environments [128]. Isolated forisomes could develop forces of 50-120 nN [129-132], which is similar to the isometric tension of the spasmoneme.

Considering that the spasmoneme was regarded as a primitive type of muscle, its maximum tension should be compared with that of skeletal muscle. Converted to tension per unit area (i.e., tensile stress) using the spasmoneme diameter of $\sim 1 \mu \mathrm{m}$, Ryu et al.'s isometric tension measurement becomes $190-420 \mathrm{kPa}$ [16], which is similar to the isometric tension of vertebrate striated muscles, 200-300 kPa [61,133]. When compared to other biological motors such as myosin, dynein and kinesin, the Vorticella spasmoneme is found to be similar to or outperform these motors in terms of tensile stress (Figure 12A).

The above comparison considers differences in size or cross-sectional area among motors using tensile stress, and it is also meaningful to take into account the mass of motors. As shown by Ryu et al. [16], the Vorticella spasmoneme can generate the isometric tension of $\sim 2.5 \times 10^{-9} \mathrm{~N}$ per $1 \mu \mathrm{m}$ length (Figure 11B). Because the average cellular density of $V$. convallaria was estimated to be $1.04 \mathrm{~g} / \mathrm{cm}^{3}$ [122], the mass of the $1 \mu \mathrm{m}$-long spasmoneme is calculated to be $8.17 \times 10^{-10} \mathrm{~kg}$. When compared to other biological motors of similar mass, the Vorticella spasmoneme appears to underperform (Figure 12B) [134,135].

Conversely the Vorticella spasmoneme surpasses other motors in terms of specific power output (power per unit mass). Previously, Mahadevan and Matsudaira evaluated that the specific power of the spasmoneme is higher than that of typical passenger car engines $(\sim 0.3 \mathrm{~W} / \mathrm{g})$ [15]. For more rigorous comparison, we have calculated the specific power of the spasmoneme using the CFD-based result of Ryu and Matsudaira [9]: the maximum power dissipation of the $\sim 117 \mu \mathrm{m}-$ long Vorticella stalk was $1.56 \mathrm{nW}$. This value corresponds to $16.3 \mathrm{~W} / \mathrm{g}$ when it is assumed that the spasmoneme length is close to the stalk length. This specific power value is four times the estimation of Mahadevan and Matsudaira, and is about two orders of magnitude higher than the specific power of car engines. This specific power of the Vorticella spasmoneme is exceptionally high even compared to mammalian skeletal muscle $(0.28 \mathrm{~W} / \mathrm{g})$ and polymer-type engineered actuators $(0.001-3.6 \mathrm{~W} / \mathrm{kg})[136,137]$. 


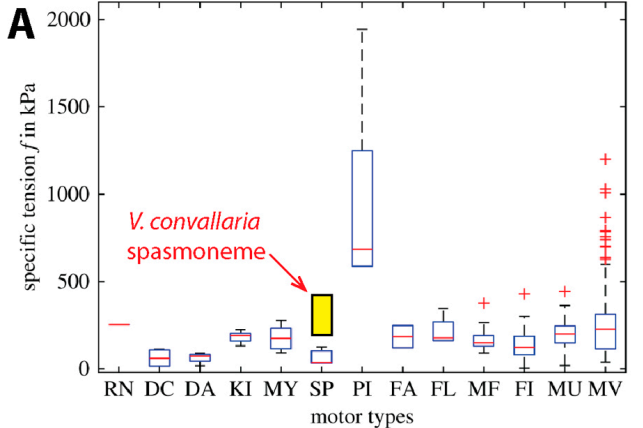

RN: RNA polymerase, DC: cyctoplasmin dynein

DA: axonemal dynein, Kl: kinesin, MY: myosin, SP: spasmoneme, PI: pili, FA: $F_{0} / F_{1}$ ATPase, FL: falgellum, MF: myofibril,

$\mathrm{FI}$ : muscular fiber, $\mathrm{MU}$ : muscle in vitro, $\mathrm{MV}$ : muscle in vivo

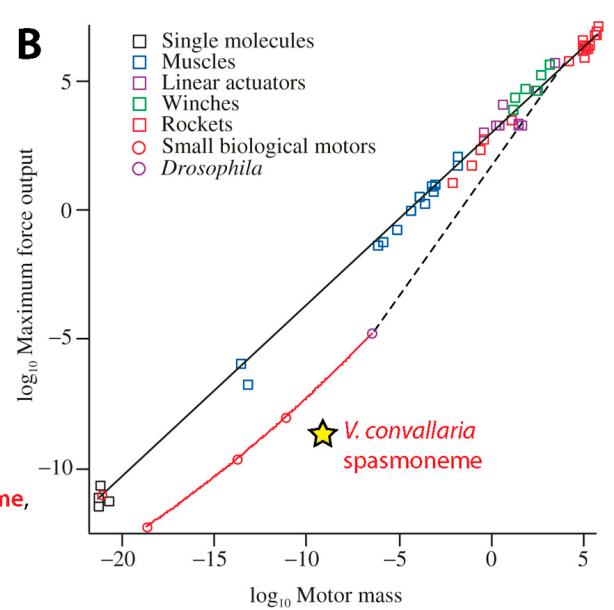

Figure 12. Comparison of the Vorticella spasmoneme with other motors. (A) Tensile stress (reproduced from [133]). Because the peak tension of live V. convallaria [14] and the isometric tension of extracted $V$. convallaria [23] are considered in [133], the isometric tensions of live V. convallaria [16] are included for rigorous comparison; (B) maximum force output $(\mathrm{N})$ with respect to their mass (kg) (reproduced from $[134,135])$.

\subsection{Possible Engineering Applications}

Because Vorticella stalks respond to concentration changes in $\mathrm{Ca}^{2+}$ or divalent cations in the medium, such stalks can operate as $\mathrm{Ca}^{2+}$-responsive actuators $[20,106]$. Similarly, $\mathrm{pH}$-responsive polymers change their shape in response to the $\mathrm{pH}$ value of the medium, and thus their applications suggest possible engineering applications of Vorticella stalks in microscale devices [138,139], such as actuating microvalves [140,141] and microlenses [142,143].

Nagai et al. demonstrated the responsive actuation of extracted $V$. convallaria cells in a microscale environment by modulating $\left[\mathrm{Ca}^{2+}\right]_{\text {free }}$ using microfluidics (Figure 13) $[144,145]$, and suggested a potential to construct $\mathrm{Ca}^{2+}$-responsive and $\mathrm{Ca}^{2+}$-powered microsystems based on Vorticellae. Then, Nagai et al. developed a $\mathrm{Ca}^{2+}$-responsive valve using Vorticella, for which a Vorticella cell was placed in a microchamber connected with a flow channel, and the extracted cell acted as a valve to open or block the channel depending on $\left[\mathrm{Ca}^{2+}\right]_{\text {free }}[146]$.

Additionally, micro-objects were successfully attached to live Vorticella using biocompatible glues such as streptavidin-biotin binding [147] and poly-L-lysine coating [148], and their reciprocal motion was achieved from the stalk motion of Vorticella. Therefore, such binding methods prove that harnessing live Vorticella for microsystem application is feasible. In addition, the motion of live Vorticella can potentially be controlled by mechanical or electrical stimulation $[11,105,119,149]$.
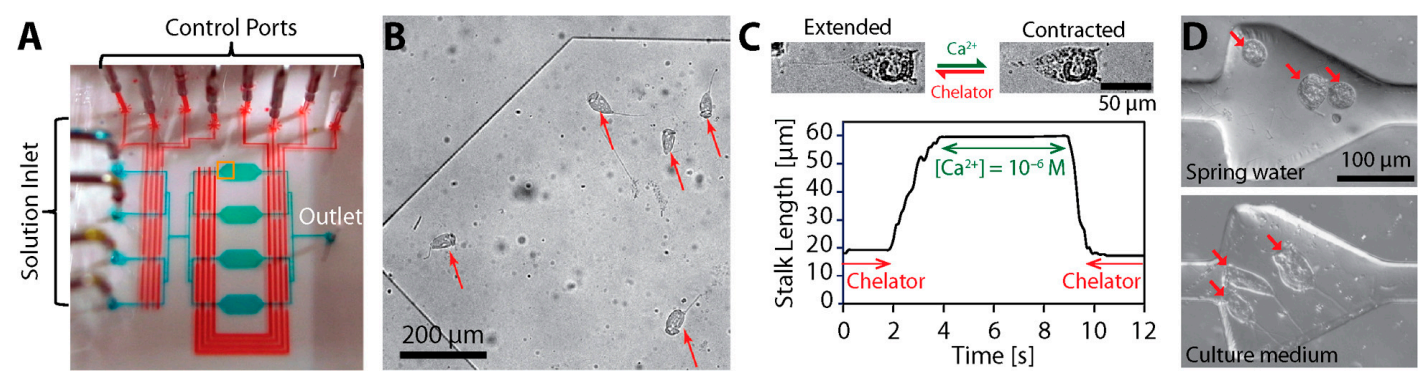

Figure 13. $V$. convallaria in a microfluidic system. (A) Microfluidic device for chemical control of extracted V. convallaria; (B) V. convallaria cells cultured in the device; (C) length change in a Vorticella stalk in a different $\left[\mathrm{Ca}^{2+}\right]_{\text {free }}$ (A-C reproduced from [145]); (D) V. convallaria cells in a single chamber of which the size is comparable to the size of the cell (reproduced from [144]). 
Table 1. Key dynamics parameters of the stalk contraction of live Vorticella and its relatives (in water).

\begin{tabular}{|c|c|c|c|c|c|c|c|}
\hline Reference & Cell & Stalk Length & $\begin{array}{c}\text { Peak Contraction } \\
\text { Speed }\end{array}$ & $\begin{array}{c}\text { Time for Peak } \\
\text { Speed }\end{array}$ & $\begin{array}{c}\text { Contraction } \\
\text { Time }\end{array}$ & $\begin{array}{l}\text { Latent } \\
\text { Period }\end{array}$ & $\begin{array}{c}\text { Contraction } \\
\text { Propagation Speed }\end{array}$ \\
\hline Ueda (1954) [32] & C. polypinum & $1.05-1.40 \mathrm{~mm}$ & $17.8-24.7 \mathrm{~cm} / \mathrm{s}$ & - & $7-10 \mathrm{~ms}$ & $2-3 \mathrm{~ms}$ & - \\
\hline Sugi (1960) [33] & C. polypinum & $0.8-2.2 \mathrm{~mm}$ & - & - & - & $1-4 \mathrm{~ms}$ & $20-50 \mathrm{~cm} / \mathrm{s}$ \\
\hline Jones et al. (1970) [119] & V. difficilis & $140-200 \mu \mathrm{m}$ & $1.4-5.6 \mathrm{~cm} / \mathrm{s}$ & - & $\sim 10 \mathrm{~ms}$ & - & $3.5-10.5 \mathrm{~cm} / \mathrm{s}$ \\
\hline Weis-Fogh and Amos (1972) [38] & Z. geniculatum & $1 \mathrm{~mm}$ & $\begin{array}{c}110 \text { length/s } \\
(11 \mathrm{~cm} / \mathrm{s})\end{array}$ & - & $5 \mathrm{~ms}$ & - & - \\
\hline Rahat et al. (1973) [39] & Carchesium & - & - & - & $40-60 \mathrm{~ms}$ & - & - \\
\hline Katoh and Naitoh (1992) [11] & Vorticella & - & $6.7 \mathrm{~cm} / \mathrm{s}$ & - & - & $1.7 \mathrm{~ms}$ & - \\
\hline Moriyama et al. (1998) [12] & V. convallaria & $\sim 250 \mu \mathrm{m}$ & $8.8 \mathrm{~cm} / \mathrm{s}$ & $2 \mathrm{~ms}$ & $\sim 9 \mathrm{~ms}$ & - & - \\
\hline Upadhyaya et al. (2008) [14] & V. convallaria & $150 \mu \mathrm{m}$ & $\sim 6 \mathrm{~cm} / \mathrm{s}$ & $\sim 2.5 \mathrm{~ms}$ & $\sim 6 \mathrm{~ms}$ & - & $\sim 10 \mathrm{~cm} / \mathrm{s}$ \\
\hline Ryu and Matsudaira (2010) [9] & V. convallaria & $117 \mu \mathrm{m}$ & $5.8 \mathrm{~cm} / \mathrm{s}$ & $1 \mathrm{~ms}$ & $3.9 \mathrm{~ms}$ & - & - \\
\hline Kamiguri et al. (2012) [120] & Vorticella & - & $4.3-7.5 \mathrm{~cm} / \mathrm{s}$ & - & - & - & - \\
\hline
\end{tabular}


Table 2. Tension and energetics of the stalk contraction of Vorticella and its relatives (in water).

\begin{tabular}{|c|c|c|c|c|c|c|c|}
\hline Reference & Cell & $\begin{array}{c}\text { Stalk (st) or } \\
\text { Spasmoneme (sp) } \\
\text { Dimension }\end{array}$ & $\begin{array}{l}\text { Contractile Force } \\
\text { or Tension }\end{array}$ & $\begin{array}{l}\text { Isometric Force } \\
\text { or Tension }\end{array}$ & Work & $\begin{array}{c}\text { Instantaneous or } \\
\text { Maximum Power } \\
\text { Output }\end{array}$ & $\begin{array}{l}\text { Energy } \\
\text { Efficiency }\end{array}$ \\
\hline Ueda (1952) [31] & $\begin{array}{l}\text { C. polypinum } \\
\text { (Live) }\end{array}$ & $\begin{array}{c}1-2.7 \text { mm long } \\
12-15 \mu \mathrm{m} \text { diameter (st) }\end{array}$ & $\begin{array}{c}0.092-0.132 \mathrm{mg} \\
(0.9-1.3 \mu \mathrm{N}) \\
65-88 \mathrm{~g} / \mathrm{cm}^{2} \\
(6.3-8.6 \mathrm{kPa})\end{array}$ & - & - & - & - \\
\hline $\begin{array}{l}\text { Hoffman-Berling } \\
\text { (1958) [17] }\end{array}$ & $\begin{array}{l}\text { Vorticella } \\
\text { (Live) }\end{array}$ & - & $\sim 10 \mathrm{kPa}[42]$ & - & - & $\sim 2.8 \mathrm{~W} / \mathrm{g}[42]$ & - \\
\hline $\operatorname{Amos}(1971)$ [13] & $\begin{array}{l}\text { Vorticella } \\
\text { (Live) }\end{array}$ & $\begin{array}{c}80 \mu \mathrm{m} \text { long } \\
1 \mu \mathrm{m} \text { diameter (sp) [44] }\end{array}$ & $\begin{array}{c}8.7 \mathrm{Nn} \\
(11 \mathrm{kPa}[44]) \\
20-30 \mathrm{~g} / \mathrm{cm}^{2}[39] \\
(1.96-2.94 \mathrm{kPa})\end{array}$ & - & $0.69 \mathrm{pJ}$ & $\begin{array}{c}2300 \mathrm{cal} / \mathrm{g} / \mathrm{h}[39] \\
(2.67 \mathrm{~W} / \mathrm{g})\end{array}$ & - \\
\hline $\begin{array}{c}\text { Weis-Fogh and } \\
\text { Amos (1972) [38] }\end{array}$ & $\begin{array}{l}\text { Z. geniculatum } \\
\text { (Glycerinated) }\end{array}$ & $\begin{array}{c}1 \mathrm{~mm} \text { long } \\
30 \mu \mathrm{m} \text { diameter }(\mathrm{sp})\end{array}$ & $30 \mathrm{kPa}[42]$ & - & - & $\sim 4 \mathrm{~W} / \mathrm{g}[42]$ & - \\
\hline Rahat et al. (1973) [39] & $\begin{array}{c}\text { Carchesium } \\
\text { (Live) }\end{array}$ & $5 \mu \mathrm{m}$ diameter $(\mathrm{sp})$ & $\begin{array}{l}400-800 \mathrm{~g} / \mathrm{cm}^{2} \\
(39.2-78.4 \mathrm{kPa})\end{array}$ & - & - & - & - \\
\hline $\begin{array}{l}\text { Moriyama et al. } \\
\text { (1996) [23] }\end{array}$ & $\begin{array}{l}\text { V. convallaria } \\
\text { (Glycerinated) }\end{array}$ & $1.0-1.2 \mu \mathrm{m}$ diameter $(\mathrm{sp})$ & - & $\begin{array}{c}40 \mathrm{nN} \text { (avg) } \\
120 \mathrm{nN}(\max ) \\
(35-51 \mathrm{kPa})\end{array}$ & - & - & $\sim 7 \%$ \\
\hline $\begin{array}{c}\text { Moriyama et al. } \\
\text { (1998) [12] }\end{array}$ & $\begin{array}{l}\text { V. convallaria } \\
\text { (Live) }\end{array}$ & $\sim 250 \mu \mathrm{m}$ long & $55.8 \mathrm{nN}$ & - & - & - & - \\
\hline France (2007) [122] & $\begin{array}{l}\text { V. convallaria } \\
\text { (Live) }\end{array}$ & - & $109-142 \mathrm{nN}$ & - & $1.93-2.59 \mathrm{pJ}$ & $0.70-0.93 \mathrm{nW}$ & - \\
\hline $\begin{array}{l}\text { Upadhyaya et al. } \\
\text { (2008) [14] }\end{array}$ & $\begin{array}{l}\text { V. convallaria } \\
\text { (Live) }\end{array}$ & $150 \mu \mathrm{m}$ long & $\sim 30 \mathrm{nN}$ & - & - & $1-3 \mathrm{nW}$ & - \\
\hline $\begin{array}{l}\text { Ryu and Matsudaira } \\
\text { (2010) [9] }\end{array}$ & $\begin{array}{l}\text { V. convallaria } \\
\text { (Live) }\end{array}$ & $117 \mu \mathrm{m}$ long & $28 \mathrm{nN}$ & - & $1.64 \mathrm{pJ}$ & $1.6 \mathrm{nW}$ & $8 \%$ \\
\hline $\begin{array}{l}\text { Apolinar-Iribe et al. } \\
\text { (2010) [123] }\end{array}$ & $\begin{array}{l}\text { Vorticella } \\
\text { (Live) }\end{array}$ & - & $117.7 \mathrm{nN}$ & - & - & - & - \\
\hline Ryu et al. (2012) [16] & $\begin{array}{l}\text { V. convallaria } \\
\text { (Live) }\end{array}$ & 49-134 $\mu \mathrm{m}$ long & - & $150-330 \mathrm{nN}$ & - & - & - \\
\hline
\end{tabular}




\section{Discussion and Future Outlook}

Microorganisms, such as bacteria or protozoa, have been integrated in microsystems to carry out specific functions, such as sensing and actuation, based on their cellular functionalities [29,150-152]. This is because such unicellular animals can self-replicate, perform multiple functions simultaneously, convert chemical energy into mechanical energy, functionally adapt to their environment, and be controlled through external stimuli. Because this approach requires sustaining the life of the integrated microorganisms, ones that can be easily cultured and maintained in various environmental conditions have been tested and utilized. Because Vorticella satisfies the above requirements, the ciliate is found to be a viable microorganism to be integrated in microsystems for flow control and actuation.

Flagellated bacteria have been employed for flow control and pumping in microfluidic systems. It was estimated that Escherichia coli rotating at 10 rounds per second could generate a flow rate of $1.7 \times 10^{-5} \mathrm{~mm}^{3} / \mathrm{s}$ [153], and tethered Serratia marcescens cells were observed to produce a flow rate of $3 \times 10^{-4} \mathrm{~mm}^{3} / \mathrm{s}$ [100]. Considering that the oral cilia of a single Vorticella cell can transport water at a flow rate of $3 \times 10^{-4} \mathrm{~mm}^{3} / \mathrm{s}$ [6], using multiple Vorticella cells would generate higher volume flow rates to control fluid flows.

For actuation, larger microorganisms have been tested in addition to bacteria [154]. A biflagellate alga Chlamydomonas reinhardtii was shown to be able to carry microscale cargo at speeds of $100-200 \mu \mathrm{m} / \mathrm{s}$ [155] and to generate force of 10-37 pN [156]. The swimming of a larger ciliate protozoan Paramecium caudatum was maneuvered to be used as a microrobot, and it was observed to swim at the maximum speed of about $2 \mathrm{~mm} / \mathrm{s}$ and to generate forces of about $27 \mathrm{nN}$ [157]. Compared with these microorganisms, live Vorticella has better actuation capabilities because it can contract faster with higher forces (Tables 1 and 2). Also, utilizing extracted Vorticella provides a unique actuation strategy to control its stalk contraction by adjusting external $\mathrm{Ca}^{2+}$ levels (Figure 13) and to convert chemical energy from $\mathrm{Ca}^{2+}$ binding to mechanical forces and motions.

However, it needs to be noticed that stalked Vorticella may not be directly compared with freely moving $C$. reinhardtii and $P$. caudatum. In the free swimming telotroch form, a stalkless Vorticella (or telotroch) swims in water using aboral cilia around the scopula $[4,158]$. When Vorticella reproduces through budding, a daughter Vorticella leaves its mother zooid and becomes a telotroch. In other cases, a sessile stalked Vorticella turns into the telotroch form when it abandons its stalk presumably to change its habitat. Upon finding a suitable habitat, the Vorticella telotroch attaches, grows a stalk from the scopula, and transforms into the sessile stalked trophont form [159]. Although swimming Vorticella cells could be utilized similarly to C. reinhardtii and P. caudatum, the swimming of stalkless Vorticella has been rarely studied. If swimming Vorticellae are to be used, furthermore, their stalk formation will need to be inhibited [160].

More efficient uses of Vorticella cells in microsystems require controlling the animal's motion. Because certain microorganisms move responding to an environmental stimulus, they can be controlled based on such taxis responses. For instance, the swimming of Paramecium was controlled using electric field based on its galvanotaxis $[157,161,162]$, and Chlamydomonas was guided by light based on its phototaxis [155]. However, little is known about what types of taxis responses Vorticella shows. Instead, it seems more probable to use magnetic particles and magnetic field to control Vorticella, as applied for controlling a ciliate protozoan Tetrahymena pyriformis [163], because such particles can be attached to or engulfed by Vorticella $[147,148]$. Controlling the stalk contraction of Vorticella is also critical for utilizing the animal as a bioactuator. The contraction of live Vorticella stalks can be induced by mechanical or electrical stimulation $[11,105,119,149]$, and extracted Vorticella stalks can be chemically controlled (Figures 8 and 13) $[17,20,21,23,145]$.

Using Vorticellae in microdevices has challenges that the viability of the live cells needs to be well maintained and that the extracted cells will denature gradually. Instead, the oral cilia and stalk of Vorticella can be mimicked to create similarly functioning devices or materials. Bioinspired cilia have been developed to create and control fluid flow in microsystems [85], and self-assembled cilia-like microtubule bundles are shown to beat and produce metachronal waves similar to cilia [97]. If such 
artificial cilia can be arranged and controlled to create circular metachronal waves mimicking the oral cilia band of Vorticella (Figure 3C), they would produce circulating flows similar to the feeding current of Vorticella (Figure 4). Similarly, if the biophysical mechanism of the spasmonemal contraction is unraveled, the $\mathrm{Ca}^{2+}$-responsive nanofibrils of the spasmoneme could be reconstructed in vitro to create spasmin-based nanoactuators, or the contraction mechanism could inspire inventing similar responsive polymers [27]. Also, the structure of the Vorticella stalk, which transforms the linear contraction of the spasmoneme into the helical coiling of the stalk (Figure 7A), can be employed for an effective design of bioinspired soft robots [164-166].

\section{Conclusions}

Using microorganisms either directly in microscale systems or as the inspiration to engineer similar biomimetic systems has the possibility to open up new frontiers in micromachinery. This is because these organisms have the unique ability to sense and actuate simultaneously. This review paper specifically introduces the sessile ciliate protozoan Vorticella as a novel and promising model organism for bio-inspired engineering, microscale fluid controllers, and calcium-sensitive and calcium-powered actuators.

Vorticella consists of a zooid with oral cilia that generate a feeding current and a slender stalk that anchors to a habitat surface. The oral cilia of Vorticella beat sequentially to form metachronal waves and generate circulating water flow with a speed of $0.4-2.5 \mathrm{~mm} / \mathrm{s}$, which translates food particles toward the zooid. This flow-generating capability of the Vorticella cilia has been successfully tested as the micromixer in microfluidic systems, but the effect of surrounding boundaries on the generated circulating flow should be considered.

The stalk of Vorticella coils in a few milliseconds, translating the zooid at a speed of $15-90 \mathrm{~mm} / \mathrm{s}$, which is driven by its calcium-powered contractile organelle, the spasmoneme. Because of its unique capability and energy source, the spasmoneme is regarded as a model organelle for bioinspired actuators. The spasmoneme can generate contractile forces of 30-330 $\mathrm{nN}$ powered by the binding of calcium ions. This spasmonemal force is comparable to the maximal force of other motors, but it has specific power much higher than other biological and man-made motors. The calcium-sensitive contractility of Vorticella has been tested for moving microscale objects in microfluidic systems. Identifying the biophysical mechanism of the spasmonemal contraction, as well as determining methods for controlled culture of Vorticella at desired locations in microfluidic devices, will increase the great potential of Vorticella within the realm of bioinspired actuators.

Acknowledgments: S.R. was supported by a Layman Seed Grant of the University of Nebraska-Lincoln and a First Award Grant of Nebraska EPSCoR. R.E.P. was supported by a fellowship from the Miller Institute for Basic Research in Science. D.C.F. was supported by the Material Measurement Laboratory at National Institute of Standards and Technology (NIST).

Author Contributions: S.R. conceived the review paper, and S.R., R.E.P., M.N. and D.C.F. wrote the paper together. Conflicts of Interest: The authors declare no conflict of interest.

\section{Abbreviations}

The following abbreviations are used in this manuscript:

$\begin{array}{ll}\text { ATP } & \text { Adenosine TriPhosphate } \\ \text { CFD } & \text { Computational Fluid Dynamics } \\ \text { ICL } & \text { InfraCilliary Lattice } \\ \text { PIV } & \text { Particle Image Velocimetry } \\ \text { PTV } & \text { Particle Tracking Velocimetry } \\ \text { TEM } & \text { Transmission Electron Microscope }\end{array}$

\section{References}

1. Van Leewenhoeck, A. Observations, communicated to the publisher by Mr. Antony van Leewenhoeck, in a Dutch letter of the 9th of Octob. 1676. Philos. Trans. R. Soc. Lond. 1677, 12, 821-831. [CrossRef] 
2. Dobell, C. Antony van Leeuwenhoek and His 'Little Animals'; Russell \& Russell Inc.: New York, NY, USA, 1958.

3. Bomfleur, B.; Kerp, H.; Taylor, T.N.; Moestrup, Ø.; Taylor, E.L. Triassic leech cocoon from Antartica contains fossil bell animal. Proc. Nat. Acad. Sci. USA 2012, 109, 20971-20974. [CrossRef] [PubMed]

4. Buhse, H.E., Jr.; Clamp, J.C. Vorticella. In Encyclopedia of Life Sciences; John Wiley \& Sons Ltd.: Chichester, UK, 2001.

5. Sleigh, M.A.; Barlow, D. Collection of food by Vorticella. Trans. Am. Microsc. Soc. 1976, 95, 482-486. [CrossRef]

6. Nagai, M.; Oishi, M.; Oshima, M.; Asai, H.; Fujita, H. Three-dimensional two-component velocity measurement of the flow field induced by the Vorticella picta microorganism using a confocal microparticle image velocimetry technique. Biomicrofluidics 2009, 3, 014105. [CrossRef] [PubMed]

7. Ruppert, E.E.; Fox, R.S.; Barnes, R.D. Invertebrate Zoology: A Functional Evolutionary Approach, 7th ed.; Thomson-Brooks/Cole: Belmont, CA, USA, 2004.

8. Pepper, R.E.; Roper, M.; Ryu, S.; Matsudaira, P.; Stone, H.A. Nearby boundaries create eddies near microscopic filter feeders. J. R. Soc. Interface 2010, 7, 851-862. [CrossRef] [PubMed]

9. Ryu, S.; Matsudaira, P. Unsteady motion, finite Reynolds numbers, and wall effect of Vorticella convallaria contribute contraction force greater than the Stokes drag. Biophys. J. 2010, 98, 2574-2581. [CrossRef] [PubMed]

10. Sugi, H. Contraction and relaxation in the stalk muscle of Carchesium. Annot. Zool. Jpn. 1959, 32, $163-169$.

11. Katoh, K.; Naitoh, Y. A mechanosensory mechanism for evoking cellular contraction in Vorticella. J. Exp. Biol. 1992, 168, 253-267.

12. Moriyama, Y.; Hiyama, S.; Asai, H. High-speed video cinematographic demonstration of stalk and zooid contraction of Vorticella convallaria. Biophys. J. 1998, 74, 487-491. [CrossRef]

13. Amos, W.B. Reversible mechanochemical cycle in the contraction of Vorticella. Nature 1971, 229, 127-128. [CrossRef] [PubMed]

14. Upadhyaya, A.; Baraban, M.; Wong, J.; Matsudaira, P.; van Oudenaarden, A.; Mahadevan, L. Power-limited contraction dynamics of Vorticella convallaria: An ultrafast biological spring. Biophys. J. 2008, 94, 265-272. [CrossRef] [PubMed]

15. Mahadevan, L.; Matsudaira, P. Motility powered by supramolecular springs and ratchets. Science 2000, 288, 95-99. [CrossRef] [PubMed]

16. Ryu, S.; Lang, M.J.; Matsudaira, P. Maximal force characterisitics of the $\mathrm{Ca}^{2+}$-powered actuator of Vorticella convallaria. Biophys. J. 2012, 103, 860-867. [CrossRef] [PubMed]

17. Hoffmann-Berling, $\mathrm{H}$. The mechanism of a new contraction cycle different from muscle contraction. Biochim. Biophys. Acta 1958, 27, 247-255. [CrossRef]

18. Townes, M.M.; Brown, D.E.S. The involvement of $\mathrm{pH}$, adenosine triphosphate, calcium, and magnesium in the contraction of the glycerinated stalks of Vorticella. J. Cell. Comp. Physiol. 1965, 65, 261-270. [CrossRef]

19. Asai, H.; Ochiai, T.; Fukui, K.; Watanabe, M.; Kano, F. Improved preparatioin and cooperative calcium contraction of glycerinated Vorticella. J. Biochem. 1978, 83, 795-798. [PubMed]

20. Ochiai, T.; Asai, H.; Fukui, K. Hysteresis of contraction-extension cycle of glycerinated Vorticella. J. Protozool. 1979, 26, 420-425. [CrossRef]

21. Ochiai, T.; Hara, R.; Asai, H. Contraction of the spasmoneme and coiling of the sheath in the glycerinated stalk of Vorticella. Cytobios 1983, 36, 95-105.

22. Asai, H.; Ochiai, T. Dependence on ionic strength of the calcium-induced contraction of glycerinated stalk of the peritrich ciliate, Vorticella convallaria. Comp. Biochem. Physiol. 1987, 87A, 565-567.

23. Moriyama, Y.; Yasuda, K.; Ishiwata, S.; Asai, H. $\mathrm{Ca}^{2+}$-induced tension development in the stalks of glycerinated Vorticella convallaria. Cell Motil. Cytoskelet. 1996, 34, 271-278. [CrossRef]

24. Vincent, J.F.V. Smart by name, smart by nature. Smart Mater. Struct. 2000, 9, 255-259. [CrossRef]

25. Lee, B.S.; Lee, S.C.; Holliday, L.S. Biochemistry of mechanoenzymes: Biological motors for nanotechnology. Biomed. Microdevices 2003, 5, 269-280. [CrossRef]

26. Knoblauch, M.; Peters, W.S. Biomimetic actuators: Where technology and cell biology merge. Cell. Mol. Life Sci. 2004, 61, 2497-2509. [CrossRef] [PubMed]

27. Huck, W.T.S. Responsive polymers for nanoscale actuations. Mater. Today 2008, 11, 24-32. [CrossRef]

28. Sareh, S.; Rossiter, J. Kirigami artificial muscles with complex biologically inspired morphologies. Smart Mater. Struct. 2013, 22, 014004. [CrossRef] 
29. Chan, V.; Asada, H.H.; Bashir, R. Utilization and control of bioactuators across multiple length scales. Lab Chip 2014, 14, 653-670. [CrossRef] [PubMed]

30. Itabashi, T.; Mikami, K.; Asai, H. Characterization of the spasmin 1 gene in Zoothamnium arbuscula strain Kawagoe (protozoa, ciliophora) and its relation to other spasmins and centrins. Res. Microbiol. 2003, 154, 361-367. [CrossRef]

31. Ueda, K. Studies on the stalk muscle of Carchesium (I). Zool. Mag. 1952, 61, 367-371.

32. Ueda, K. Electri stimulation of the stalk muscle of Carchesium II. Zool. Mag. 1954, 63, 9-14.

33. Sugi, H. Propagation of contraction in the stalk muscle of Carchesium. J. Fac. Sci. Univ. Tokyo Sect. IV Zool. 1960, 8, 603-615.

34. Sugi, H. Volume change during contraction in the stalk muscle of Carchesium. J. Fac. Sci. Univ. Tokyo Sect. IV Zool. 1961, 9, 155-170.

35. Randall, J.T.; Hopkins, J.M. On the stalks of certain peritrichs. Philol. Trans. B 1962, 245, 59-79. [CrossRef]

36. Rahat, M.; Parnas, I.; Nevo, A.C. Extensibility and tensile strength of the stalk "muscle" of Carchesium sp. Exp. Cell Res. 1969, 54, 69-76. [CrossRef]

37. Amos, W.B. Structure and coiling of the stalk in the peritrich ciliates Vorticella and Carchesium. J. Cell Sci. 1972, 10, 95-122. [PubMed]

38. Weis-Fogh, T.; Amos, W.B. Evidence for a new mechanism of cell motility. Nature 1972, 236, 301-304. [CrossRef] [PubMed]

39. Rahat, M.; Pri-Paz, Y.; Parnas, I. Properties of stalk-'muscle' contractions of Carchesium sp. J. Exp. Biol. 1973, 58, 463-471.

40. Routledge, L.M.; Amos, W.B.; Gupta, B.L.; Hall, T.A.; Weis-Fogh, T. Microprobe measurements of calcium binding in the contractile spasmoneme of a Vorticellid. J. Cell Sci. 1975, 19, 195-201. [PubMed]

41. Amos, W.B.; Routledge, L.M.; Yew, F.F. Calcium-binding proteins in a Vorticellid contractile organelle. J. Cell Sci. 1975, 19, 203-213. [PubMed]

42. Weis-Fogh, T. Principles of contraction in the spasmoneme of verticellids. A new contractile system. In Comparative Physiology_Functional Aspects of Structural Materials; Bolis, L., Maddrell, H.P., Schmidt-Nielsen, K., Eds.; North-Holland Publishing Company: Amsterdam, The Netherlands, 1975; pp. 83-98.

43. Amos, W.B. Structure and protein composition of the spasmoneme. In Comparative Physiology-Functional Aspects of Structural Materials; Bolis, L., Maddrell, H.P., Schmidt-Nielsen, K., Eds.; North-Holland Publishing Company: Amsterdam, The Netherlands, 1975; pp. 99-104.

44. Amos, W.B. Contraction and calcium binding in the Vorticellid ciliates. In Molecules and Cell Movement; Inoue, S., Stephens, R.E., Eds.; Raven Press: New York, NY, USA, 1975; pp. 411-435.

45. Amos, W.B.; Routledge, L.M.; Weis-Fogh, T.; Yew, F.F. The spasmoneme and calcium-dependent contraction in connection with specific calcium binding proteins. In Proceedings of the Symposia of the Society for Experimental Biology, Englefield Green, Surrey, UK, 9-12 September 1975; Cambridge University Press: Englefield Green, UK, 1976.

46. Hawkes, R.B.; Rahat, M. Contraction and volume reduction of the glycerolated Carchesium spasmoneme: Effects of alkali earth cations. Experientia 1976, 32, 160-162. [CrossRef]

47. Hawkes, R.B. Carchesium stalk fibrillar matrix as a highly filled polymer network. J. Cell. Physiol. 1977, 90, 31-40. [CrossRef] [PubMed]

48. Routledge, L.M.; Amos, W.B.; Yew, F.F.; Weis-Fogh, T. New calcium-binding contractile proteins. In Cell Motility Book A: Motility, Muscle and Non-Muscle Cells; Goldman, R., Pollard, T., Rosenbaum, J., Eds.; Cold Spring Harbor Laboratory Press: Cold Spring Harbor, NY, USA, 1976; pp. 93-113.

49. Routledge, L.M. Calcium-binding proteins in the Vorticellid spasmoneme: Extraction and characterization by gel electrophoresis. J. Cell Biol. 1978, 77, 358-370. [CrossRef] [PubMed]

50. Moreton, R.B.; Amos, W.B. Electrical recording from the contractile ciliate Zoothamnium geniulatum ayrton. J. Exp. Biol. 1979, 83, 159-167.

51. Yamada, K.; Asai, H. Extraction and some properties of the proteins, Spastin B, from the spasmoneme of Carchesium polypinum. J. Biochem. 1982, 91, 1187-1195. [PubMed]

52. Yamada-Horiuchi, K.; Asai, H. Partial purification of the $\mathrm{Ca}^{2+}$-binding proteins from the spasmoneme of Carchesium. Comp. Biochem. Physiol. 1985, 81, 409-413. [CrossRef] 
53. Yamada-Horiuchi, K.; Asai, H. Circular dichroism studies of the $\mathrm{Ca}^{2+}$-binding proteins from the spasmoneme of Carchesium. Comp. Biochem. Physiol. 1985, 81B, 927-931. [CrossRef]

54. Ochiai, T.; Kato, M.; Ogawa, T.; Asai, H. Spasmin-like proteins in various ciliates revealed by antibody to purified spasmins of Carchesium polypinum. Experientia 1988, 44, 768-771. [CrossRef] [PubMed]

55. Asai, H.; Ninomiya, T.; Kono, R.; Moriyama, Y. Spasmin and a putative spasmin binding protein(s) isolated from solubilized spasmonemes. J. Eukaryot. Microbiol. 1998, 45, 33-39. [CrossRef]

56. Moriyama, Y.; Okamoto, H.; Asai, H. Rubber-like elasticity and volume change in the isolated spasmoneme of Giant Zoothamnium sp. under $\mathrm{Ca}^{2+}$-induced contraction. Biophys. J. 1999, 76, 993-1000. [CrossRef]

57. Itabashi, T.; Terasaki, T.; Asai, H. Novel nuclear and cytoplasmic proteins detected by Anti-Zoothamnium arbuscula (protozoa) spasmin 1 antibody in mammalian cells are dependent on the cell cycle. J. Biochem. 2004, 136, 651-657. [CrossRef] [PubMed]

58. Asai, H. $\mathrm{Ca}^{2+}$-driven contraction of spasmoneme in Vorticellidae. Jpn. J. Protozool. 2005, 38, 133-152.

59. Rahat, M.; Friedlaender, H.; Pimstein, R. Colchicine inhibition of stalk elongation in Carchesium sp.: Effect of $\mathrm{Ca}^{2+}$ and $\mathrm{Mg}^{2+}$. J. Cell Sci. 1975, 19, 183-193. [PubMed]

60. Buhse, H.E., Jr. Vorticella: “A cell for all seasons". J. Eukaryot. Microbiol. 1998, 45, 469-474. [CrossRef]

61. Bray, D. Cell Movements: From Molecules to Motility, 2nd ed.; Garland Publishing: New York, NY, USA, 2001.

62. Lodish, H.; Berk, A.; Matsudaira, P.; Kaiser, C.A.; Krieger, M.; Scott, M.P. Molecular Cell Biology, 5th ed.; Freeman W. H. and Company: New York, NY, USA, 2004.

63. Linck, R.W. Cilia and flagella. In Encyclopedia of Life Sciences; John Wiley \& Sons Ltd.: Chichester, UK, 2009.

64. Brennen, C.; Winet, H. Fluid mechanics of propulsion by cilia and flagella. Ann. Rev. Fluid Mech. 1977, 9, 339-398. [CrossRef]

65. Subramanian, G.; Nott, P.R. The fluid dynamics of swimming microorganisms and cells. J. Indian Inst. Sci. 2011, 91, 383-413.

66. Guasto, J.S.; Rusconi, R.; Stocker, R. Fluid mechanics of planktonic microorganisms. Annu. Rev. Fluid Mech. 2012, 44, 373-400. [CrossRef]

67. Allen, R.D. Structures linking the myonemes, endoplasmic reticulum, and surface membranes in the contractile ciliate Vorticella. J. Cell Biol. 1973, 56, 559-579. [CrossRef] [PubMed]

68. Paramecium and Other Ciliates: Richard Allen's Image Collection. Available online: http://www5.pbrc. hawaii.edu/allen/ch19/21-vor720307--15.html. (accessed on 13 October 2016).

69. Vopel, K.; Reick, C.H.; Arlt, G.; Pohn, M.; Ott, J. Flow microenvironment of two marine peritrich ciliates with ecobiotic chemoautotrophic bacteria. Aquat. Microb. Ecol. 2002, 29, 19-28. [CrossRef]

70. Vogel, S. Life in Moving Fluids; Princeton University Press: Princeton, NJ, USA, 1994.

71. Blake, J.R.; Liron, N.; Aldis, G.K. Flow patterns around ciliated microorganisms and in ciliated ducts. J. Theor. Biol. 1982, 98, 127-141. [CrossRef]

72. Blake, J.R.; Otto, S.R. Ciliary propulsion, chaotic filtration and a 'blinking' stokeslet. J. Eng. Math. 1996, 30, 151-168. [CrossRef]

73. Blake, J.R.; Otto, S.R.; Blake, D.A. Filter feeding, chaotic filtration and a blinking Stokeslet. Theor. Comput. Fluid Dyn. 1998, 10, 23-36. [CrossRef]

74. Liron, N.; Blake, J.R. Existence of viscous eddies near boundaries. J. Fluid Mech. 1981, 107, 109-129. [CrossRef]

75. Liron, N.; Mochon, S. Stokes flow for a stokeslet between two parallel flat plates. J. Eng. Math. 1976, 10, 287-303. [CrossRef]

76. Pettitt, M.E.; Orme, B.A.A.; Blake, J.R.; Leadbeater, B.S.C. The hydrodynamics of filter feeding in choanoflagellates. Eur. J. Protistol. 2002, 38, 313-332. [CrossRef]

77. Liron, N. Fluid transport by cilia between parallel plates. J. Fluid Mech. 1978, 86, 705-726. [CrossRef]

78. Orme, B.A.A.; Blake, J.R.; Otto, S.R. Modelling the motion of particles around choanoflagellates. J. Fluid Mech. 2003, 475, 333-355. [CrossRef]

79. Fenchel, T. Protozoan filter feeding. Prog. Protistol. 1986, 2, 65-113.

80. Hartmann, C.; Ozlemzmutlu, O.; Petermeier, H.; Fried, J.; Delgado, A. Analysis of the flow field induced by the sessile peritrichious ciliate Opercularia asymmetrica. J. Biomech. 2007, 40, 137-148. [CrossRef] [PubMed]

81. Otto, S.R.; Yannacopoulos, A.N.; Blake, J.R. Transport and mixing in Stokes flow: The effect of chaotic dynamics on the blinking stokeslet. J. Fluid Mech. 2001, 430, 1-26. [CrossRef]

82. Orme, A.A.; Otto, S.R.; Blake, J.R. Enhanced efficiency of feeding and mixing due to chaotic flow patterns around choanoflagellates. Math. Med. Biol. 2001, 18, 293-325. [CrossRef] 
83. Roper, M.; Dayle, M.J.; Pepper, R.E.; Koehl, M.A.R. Cooperatively generated stresslet flows supply fresh fluid to multicellular choanoflagellate colonies. Phys. Rev. Lett. 2013, 110, 228104. [CrossRef] [PubMed]

84. Pepper, R.E.; Roper, M.; Ryu, S.; Matsumoto, N.; Nagai, M.; Stone, H.A. A new angle on microscopic suspension feeders near boundaries. Biophys. J. 2013, 105, 1796-1804. [CrossRef] [PubMed]

85. Den Toonder, J.M.J.; Onck, P.R. Microfluidic manipulation with artificial/bioinspired cilia. Trends Biotechnol. 2013, 31, 85-91. [CrossRef] [PubMed]

86. Den Toonder, J.; Bos, F.; Broer, D.J.; Filippini, L.; Gillies, M.; de Goede, J.; Mol, T.; Reijme, M.; Talen, W.; Wilderbeck, H.; et al. Artificial cilia for active micro-fluidic mixing. Lab Chip 2008, 8, 533-541. [CrossRef] [PubMed]

87. Baltussen, M.; Anderson, P.; Bos, F.; den Toonder, J. Interial flow effects in a micro-mixer based on artificial cilia. Lab Chip 2009, 9, 2326-2331. [CrossRef] [PubMed]

88. Fahrni, F.; Prins, M.W.J.; van IJzendoorn, L.J. Micro-fluidic actuation using magnetic artificial cilia. Lab Chip 2009, 9, 3413-3421. [CrossRef] [PubMed]

89. Oh, K.; Chung, J.-H.; Devasia, S.; Riley, J.J. Bio-mimetic silicone cilia for microfluidic manipulation. Lab Chip 2009, 9, 1561-1566. [CrossRef] [PubMed]

90. Vilfan, M.; Potocnik, A.; Kavcic, B.; Osterman, N.; Poberaj, I.; vilfan, A.; Babic, D. Self-assembled artificial cilia. Proc. Natl. Acad. Sci. USA 2009, 107, 1844-1847. [CrossRef] [PubMed]

91. Oh, K.; Smith, B.; Devasia, S.; Riley, J.J.; Chung, J.-H. Characterization of mixing performance for bio-mimetic silicone cilia. Microfluid. Nanofluid. 2010, 9, 645-655. [CrossRef]

92. Shields, A.R.; Fiser, B.L.; Evans, B.A.; Falvo, M.R.; Washburn, S.; Superfine, R. Biomimetic cilia arrays generate simultaneous pumping and mixing regimes. Proc. Natl. Acad. Sci. USA 2010, 107, 15670-15675. [CrossRef] [PubMed]

93. Coq, N.; Bricard, A.; Delapierre, F.-D.; Malaquin, L.; du Roure, O.; Fermigier, M.; Bartolo, D. Collective beating of artificial microcilia. Phys. Rev. Lett. 2011, 107, 014501. [CrossRef] [PubMed]

94. Hussong, J.; Schorr, N.; Belardi, J.; Prucker, O.; Ruhe, J.; Westerweel, J. Experimental investigation of the flow induced by artificial cilia. Lab Chip 2011, 11, 2017-2022. [CrossRef] [PubMed]

95. Khaderi, S.N.; Craus, C.B.; Hussong, J.; Schorr, N.; Belardi, J.; Westerweel, J.; Prucker, O.; Ruhe, J.; den Toonder, J.M.J.; Onck, P.R. Magnetically-actuated artificial cilia for microfluidic propulsion. Lab Chip 2011, 11, 2002-2010. [CrossRef] [PubMed]

96. Kokot, G.; Vilfan, M.; Osterman, N.; Vilfan, A.; Kavcic, B.; Poberaj, I.; Babic, D. Measurement of fluid flow generated by artificial cilia. Biomicrofluidics 2011, 5, 034103. [CrossRef] [PubMed]

97. Sanchez, T.; Welch, D.; Nicastro, D.; Dogic, Z. Cilia-like beating of active microtubule bundles. Science 2011, 333, 456-459. [CrossRef] [PubMed]

98. Darnton, N.; Turner, L.; Breuer, K.; Berg, H.C. Moving fluid with bacterial carpets. Biophys. J. 2004, 86, 1863-1870. [CrossRef]

99. Kim, M.J.; Breuer, K.S. Use of bacterial carpets to enhance mixing in microfluidic systems. J. Fluid Eng. 2007, 129, 319-324. [CrossRef]

100. Kim, M.J.; Breuer, K.S. Microfluidic pump powered by self-organizing bacteria. Small 2008, 4, 111-118. [CrossRef] [PubMed]

101. Nagai, M.; Hasayaka, Y.; Kato, K.; Kawashima, T.; Shibata, T. Mixing of solutions by coordinated ciliary motion in Vorticella convallaria and patterning method for microfluidic applications. Sens. Actuat. B Chem. 2013, 188, 1255-1262. [CrossRef]

102. Nagai, M.; Hayasaka, Y.; Kawashima, T.; Shibata, T. Active mixing in microchamber using cilia of Vorticella convallaria. IEEJ Trans. Electr. Electron. Eng. 2014, 9, 575-576. [CrossRef]

103. Nagai, M.; Tanizaki, K.; Hayasaka, Y.; Kawashima, T.; Shibata, T. A microfluidic flow-switching device powered by Vorticella stalk. J. Phys. 2013, 433, 012014.

104. Allen, R.D. Contractility and its control in peritrich ciliates. J. Eukaryot. Microbiol. 1973, 20, 25-36. [CrossRef]

105. Katoh, K.; Kikuyama, M. An all-or-nothing rise in cytosolic $\left[\mathrm{Ca}^{2+}\right]$ in Vorticella sp. J. Exp. Biol. 1997, 200, 35-40. [PubMed]

106. Yokoyama, Y.; Asai, H. Contractiliy of the spasmoneme in glycerinated Vorticella stalk induced by various divalent metal and lanthanide ions. Cell Motil. Cytoskelet. 1987, 7, 39-45. [CrossRef] 
107. Gogendeau, D.; Beisson, J.; de Loubresse, N.G.; Le Caer, J.-P.; Ruiz, F.; Cohen, J.; Sperling, L.; Koll, F.; Klotz, C. An sfilp-like centrin-binding protein mediates centrin-based $\mathrm{Ca}^{2+}$-dependent contractility in Paramecium tetraurelia. Eukaryot. Cell 2007, 6, 1992-2000. [CrossRef] [PubMed]

108. Baek, N.; Park, K. Natural polymer gels with fast responses. In Reflexive Polymers and Hydrogels: Understanding and Designing Fast Responsive Polymeric Systems; Yui, N., Mrsny, R.J., Park, K., Eds.; CRC Press LLC: Boca Raton, FL, USA, 2004; pp. 86-96.

109. Fang, J.; Zhang, B.; Asai, H. Chemical modification of contractile 3-nm-diameter filaments in Vorticella spasmoneme by diethyl-pyrocarbonate and its reversible renaturation by hydroxylamine. Biochem. Biophys. Res. Commun. 2003, 310, 1067-1072. [CrossRef] [PubMed]

110. Asai, H. Structure and function of general motor proteins systems for motility, including the spasmoneme in Vorticellidae stalk. Jpn. J. Protozool. 2006, 39, 104-106.

111. Schiebel, E.; Bornens, M. In search of a function for centrins. Trends Cell Biol. 1995, 5, 197-201. [CrossRef]

112. Kono, R.; Ochiai, T.; Asai, H. Chemical modification of amino acid residue in glycerinated Vorticella stalk and $\mathrm{Ca}^{2+}$-induced contractility. Cell Motil. Cytoskelet. 1997, 36, 305-312. [CrossRef]

113. Dantas, T.J.; Daly, O.M.; Morrison, C.G. Such small hands: The roles of centrins/caltractins in the centriole and in genome maintenance. Cell. Mol. Life Sci. 2012, 69, 2979-2997. [CrossRef] [PubMed]

114. Zhang, Y.; He, C.Y. Centrins in unicellular organisms: Functional diversity and specialization. Protoplasma 2012, 249, 459-467. [CrossRef] [PubMed]

115. Salisbury, J.L. Roots. J. Eukaryot. Microbiol. 1998, 45, 28-32. [CrossRef] [PubMed]

116. Kilmartin, J.V. Sfi1p has conserved centrin-binding sites and an essential function in budding yeast spindle pole body duplication. J. Cell Biol. 2003, 162, 1211-1221. [CrossRef] [PubMed]

117. Salisbury, J.L. Centrosomes: Sfi1p and centrin unravel a structural riddle. Curr. Biol. 2004, 14, R27-R29. [CrossRef] [PubMed]

118. Li, S.; Sandercock, A.M.; Conduit, P.; Robinson, C.V.; Williams, R.L.; Kilmartin, J.V. Structural role of Sfi1p-centrin filaments in budding yeast spindle pole body duplication. J. Cell Biol. 2006, 173, 867-877. [CrossRef] [PubMed]

119. Jones, A.R.; Jahn, T.L.; Fonesca, J. Contraction of protoplasm IV. Cinematographic analysis of the contraction of some peritrichs. J. Cell. Physiol. 1970, 75, 9-20. [CrossRef] [PubMed]

120. Kamiguri, J.; Tsuchiya, N.; Hidema, R.; Tachibana, M.; Yatabe, Z.; Shoji, M.; Hashimoto, C.; Pansu, R.B.; Ushiki, H. Contraction behaviors of Vorticella sp. stalk investigated using high-speed video camera. I: Nucleation and growth model. Biophysics 2012, 8, 1-9. [CrossRef] [PubMed]

121. Kamiguri, J.; Tsuchiya, N.; Hidema, R.; Yatabe, Z.; Shoji, M.; Hashimoto, C.; Pansu, R.B.; Ushiki, H. Contraction behaviors of Vorticella sp. stalk investigated using high-speed video camera. II: Viscosity effect of several types of polymer additives. Biophysics 2012, 8, 11-19. [CrossRef] [PubMed]

122. France, D.C. Structure and Mechanics of the Spasmoneme, a Biological Spring within the Protozoan Vorticella convallaria; Massachusetts Institute of Technology: Cambridge, MA, USA, 2007.

123. Apolinar-Iribe, A.; Virgen-Ortiz, A.; Marin, J.L.; Muniz, J. Measurement of Vorticella contraction force using a micropipette technique. Adv. Sci. Lett. 2010, 3, 482-485. [CrossRef]

124. Knoblauch, M.; Peters, W.S. Forisomes, a novel type of $\mathrm{Ca}^{2+}$-dependent contractile protein motor. Cell Motil. Cytoskelet. 2004, 58, 137-142. [CrossRef] [PubMed]

125. Tuteja, N.; Umate, P.; van Bel, A.J.E. Forisomes: Calcium-powered protein complexes with potential as 'smart' biomaterials. Trends Biotechnol. 2009, 28, 102-110. [CrossRef] [PubMed]

126. Shen, A.Q.; Hamlington, B.D.; Knoblauch, M.; Peters, W.S.; Pickard, W.F. Forisome based biomimetic smart materials. Smart Struct. Syst. 2006, 2, 225-235. [CrossRef]

127. Noll, G.A.; Müller, B.; Ernst, A.M.; Rüping, B.; Twyman, R.M.; Prüfer, D. Native and artificial forisomes: Functions and applications. Appl. Microbiol. Biotechnol. 2011, 89, 1675-1682. [CrossRef] [PubMed]

128. Knoblauch, M.; Peters, W.S.; Ehlers, K.; van Bel, A.J.E. Reversible calcium-regulated stopcoks in legume sieve tubes. Plant Cell 2001, 13, 1221-1230. [CrossRef] [PubMed]

129. Knoblauch, M.; Noll, G.A.; Müller, T.; Prüfer, D.; Schneider-Hüther, I.; Scharner, D.; Van Bel, A.J.E.; Peters, W.S. ATP-independent contractile proteins from plants. Nat. Mater. 2003, 2, 600-603. [CrossRef] [PubMed]

130. Schwan, S.; Fritzsche, M.; Cismak, A.; Heilmann, A.; Spohn, U. In vitro investigation of the geometric contraction behavior of chemo-mechanical P-protein aggregates (forisomes). Biophys. Chem. 2007, 125, 444-452. [CrossRef] [PubMed] 
131. Schwan, S.; Ferrell, N.; Hansford, D.; Spohn, U.; Heilmann, A. Measurement of mechanical forces generated by plant P-protein aggregates (forisomes). Eur. Biophys. J. 2009, 38, 533-536. [CrossRef] [PubMed]

132. Schwan, S.; Menzel, M.; Fritzsche, M.; Heilmann, A.; Spohn, U. Micromechanical measurements on P-protein aggregates (forisomes) from Vicia faba plants. Biophys. Chem. 2009, 139, 99-105. [CrossRef] [PubMed]

133. Rospars, J.-P.; Meyer-Vernet, N. Force per cross-sectional area from molecules to muscles: A general property of biological motors. R. Soc. Open Sci. 2016, 3, 160313. [CrossRef] [PubMed]

134. Marden, J.H.; Allen, L.R. Molecules, muscles, and machines: Universal performance characteristics of motors. Proc. Natl. Acad. Sci. USA 2002, 99, 4161-4166. [CrossRef] [PubMed]

135. Marden, J.H. Scaling of maximum net force output by motors used for locomotion. J. Exp. Biol. 2005, 208, 1653-1664. [CrossRef] [PubMed]

136. Hunter, I.W.; Lafontaine, S. A comparison of muscle with artificial actuators. In Proceedings of the IEEE Solid-State Sensor and Actuator Workshop, Hilton Head Island, SC, USA, 22-25 June 1992; pp. 178-185.

137. Madden, J.D.W.; Vandesteeg, N.A.; Anquetil, P.A.; Madden, P.G.A.; Takshi, A.; Pytel, R.Z.; Lafontaine, S.R.; Wieringa, P.A.; Hunter, I.W. Artificial muscle technology: Physical principles and naval prospects. IEEE J. Ocean. Eng. 2004, 29, 706-728. [CrossRef]

138. Argentiere, S.; Gigli, G.; Mortato, M.; Gerges, I.; Blasi, L. Smart microfluidics: The role of stimuli-responsive polymers in microfluidic devices. In Advances in Microfluidics; Kelly, R., Ed.; InTech: Rijeka, Croatia, 2012; pp. 127-154.

139. Dong, L.; Jiang, H. Autonomous microfluidics with stimuli-responsive hydrogels. Soft Matter 2007, 3, 1223-1230. [CrossRef]

140. Beebe, D.J.; Moore, J.S.; Bauer, J.M.; Yu, Q.; Liu, R.H.; Devadoss, C.; Jo, B.-H. Functional hydrogel structures for autonomous flow control inside microfluidic channels. Nature 2000, 404, 588-590. [CrossRef] [PubMed]

141. Liu, R.H.; Yu, Q.; Beebe, D.J. Fabrication and characterization of hydrogel-based microvalves. J. Microelectromech. Syst. 2002, 11, 45-53. [CrossRef]

142. Dong, L.; Agarwal, A.K.; Beebe, D.J.; Jiang, H. Adaptive liquid microlenses activated by stimuli-responsive hydrogels. Nature 2006, 442, 551-554. [CrossRef] [PubMed]

143. Dong, L.; Agarwal, A.K.; Beebe, D.J.; Jiang, H. Variable-focus liquid microlenses and microlens arrays actuated by thermoresponsive hydrogels. Adv. Mater. 2007, 19, 401-405. [CrossRef]

144. Nagai, M.; Matsumoto, N.; Kawashima, T.; Shibata, T. Reversible motion control of Vorticella stalk in microchannel. Microelectron. Eng. 2013, 108, 28-32. [CrossRef]

145. Nagai, M.; Ryu, S.; Thorsen, T.; Matsudaira, P.; Fujita, H. Chemical control of Vorticella bioactuator using microfluidics. Lab Chip 2010, 10, 1574-1578. [CrossRef] [PubMed]

146. Nagai, M.; Tanizaki, K.; Hayasaka, Y.; Kawashima, T.; Shibata, T. Microfluidic cellular valve powered by linear bioactuator. In Proceedings of the 2013 Transducers \& Eurosensors XXVII: The 17th International Conference on Solid-State Sensors, Actuators and Microsystems, Barcelona, Spain, 16-20 June 2013; pp. 1699-1702.

147. Nagai, M.; Kumemura, M.; Asai, H.; Fujita, H. Binding of artificial object to Vorticella for a microsystem powered by a microorganism. e-J. Surf. Sci. Nanotechnol. 2009, 7, 673-676. [CrossRef]

148. Nagai, M.; Asai, H.; Fujita, H. Reciprocation of micro-objects by contraction and extension of Vorticella convallaria using polylysine as adhesive material. Mech. Eng. J. 2014, 1. [CrossRef]

149. Patterson, D.J. Habituation in a protozoan Vorticella convallaria. Behavior 1973, 45, 304-311. [CrossRef]

150. Tanaka, Y.; Sato, K.; Shimizu, T.; Yamato, M.; Okano, T.; Kitamori, T. Biological cells on microchips: New technologies and applications. Biosens. Bioelectron. 2007, 23, 449-458. [CrossRef] [PubMed]

151. Charlsen, R.W.; Sitti, M. Bio-hybrid cell-based actuators for microsystems. Small 2014, 10, 3831-3851. [CrossRef] [PubMed]

152. Martel, S. Bacterial microsystems and microrobots. Biomed. Microdevices 2012, 14, 1033-1045. [CrossRef] [PubMed]

153. Tung, S.; Kim, J.W. Microscale hybrid devices powered by biological flagellar motors. IEEE. Trans. Autom. Sci. Eng. 2006, 3, 260-263. [CrossRef]

154. Steager, E.B.; Sakar, M.S.; Kim, D.H.; Kumar, V.; Pappas, G.J.; Kim, M.J. Electrokinetic and optical control of bacterial microrobots. J. Micromech. Microeng. 2011, 21, 035001. [CrossRef]

155. Weibel, D.B.; Garstecki, P.; Ryan, D.; DiLuzio, W.R.; Mayer, M.; Seto, J.E.; Whitesides, G.M. Microoxen: Microorganisms to move microscale loads. Proc. Natl. Acad. Sci. USA 2005, 102, 11963-11967. [CrossRef] [PubMed] 
156. McCord, R.P.; Yukich, J.N.; Bernd, K.K. Analysis of force generation during flagellar assembly through optical trapping of free-swimming Chlamydomonas reinhardtii. Cell Motil. Cytoskelet. 2005, 61, 137-144. [CrossRef] [PubMed]

157. Itoh, A. Motion control of protozoa for bio-MEMS. IEEE/ASME Trans. Mechatron. 2000, 5, 181-188. [CrossRef]

158. Vacchiano, E.; Dreisbach, A.; Locascio, D.; Castaneda, L.; Vivian, T.; Bushe, H.E., Jr. Morphogenetic transitions and cytoskeletal elements of the stalked zooid and the telotroch stages in the peritrich ciliate Vorticella convallaria. J. Protozool. 1992, 39, 101-106. [CrossRef]

159. De Baufer, P.J.; Amin, A.A.; Pak, S.C.; Buhse, H.E., Jr. A method for the synchronous induction of large numbers of telotrochs in vorticella convallaria by monocalcium phosphate at low $\mathrm{pH}$. J. Eukaryot. Microbiol. 1999, 46, 12-16. [CrossRef]

160. Bramucci, M.G.; Nagarajan, V. Inhibition of Vorticella microstoma stalk formation by wheat germ agglutinin. J. Eukaryot. Microbiol. 2004, 51, 425-427. [CrossRef] [PubMed]

161. Fearing, R.S. Control of a micro-organism as a prototype micro-robot. In Proceedings of the 2nd International Symposium on Micromachines and Human Sciences, Nagoya, Japan, 9 October 1991.

162. Ogawa, N.; Oku, H.; Hashimoto, K. Microrobotic visual control of motile cells using high-speed tracking system. IEEE Trans. Robot. 2005, 21, 704-712. [CrossRef]

163. Kim, D.H.; Casale, D.; Kohidai, L.; Kim, M.J. Galvanotactic and phototactic control of Tetrahymena pyriformis as a microfluidic workhorse. Appl. Phys. Lett. 2009, 94, 163901. [CrossRef]

164. Kim, S.; Laschi, C.; Trimmer, B. Soft robotics: A bioinspired evolution in robotics. Trends Biotechnol. 2013, 31, 287-294. [CrossRef] [PubMed]

165. Feinberg, A.W. Biological soft robotics. Annu. Rev. Biomed. Eng. 2015, 17, 243-265. [CrossRef] [PubMed]

166. Rus, D.; Tolley, M.T. Design, fabrication and control of soft robots. Nature 2015, 521, 467-475. [CrossRef] [PubMed]

(C) 2016 by the authors; licensee MDPI, Basel, Switzerland. This article is an open access article distributed under the terms and conditions of the Creative Commons Attribution (CC-BY) license (http://creativecommons.org/licenses/by/4.0/). 